\title{
"Del tamaño de una uña”. Reliquias, devociones y mística en una ciudad novohispana. Puebla de los Ángeles, siglo XVII
}

\author{
"About the Size of a Fingernail". Relics, Devotions and Mysticism \\ in a City in New Spain. 17 th-century Puebla de los Ángeles

\section{Rosalva Loreto López} \\ BENEMÉRITA UNIVERSIDAD AUTÓNOMA DE PUEBLA, rloreto13@yahoo.com.mx
}

El primer convento de la Orden de las Carmelitas descalzas en el Nuevo Mundo se fundó en 1604. Varias razones confluyeron para su posterior afianzamiento y exitosa expansión. Una de éstas obedeció a la necesidad de proporcionar espacios de clausura para las descendientes de españoles. Otro elemento decisivo tuvo que ver con la rápida beatificación de Teresa de Jesús en 1614. Cuatro años después, una reliquia del brazo de la Santa llegó al convento en Puebla e inspiró a catorce religiosas a tener visiones. Éstas fueron descritas en 22 páginas que conforman el manuscrito analizado en este estudio. Estas descripciones reafirmaron las ideas teológicas del cristocentrismo enmarcadas por la mística y la ascética del barroco.

PALABRAS CLAVE: monjas, religiosidad, comunidades emocionales.

The first convent of the Carmelite Order for women in the New World was founded in 1604. Among the reasons for its rapid consolidation and successful expansion in New Spain [Mexico] was the need to create cloistered communities for women of Spanish descent, but the quick beatification of Teresa de Jesus in 1614 was a second important contributing factor. Four years later, a relic from Santa Teresa's arm arrived at the convent in Puebla, and fourteen nuns experienced visions inspired by it. These events were recorded in the 22-page manuscript analyzed in this study, whose descriptions reaffirmed theological ideas related to Christocentrism, framed by mysticism and the aesthetics of the early Baroque period.

KEYwORDS: nuns, religiosity, emotional communities.

Fecha de recepción del artículo: 28 de junio de 2016 / Fecha de aprobación: 25 de enero de 2017 / Fecha de recepción de la versión final: 28 de febrero de 2017

1 primer convento de carmelitas descalzas de la América his-
pánica se fundó en la ciudad de Puebla de los Ángeles en
1604 bajo la advocación del señor San José, de hecho se pue-
de considerar el primer monasterio de la orden carmelitana en el orbe
americano, de éste se desprendieron dos monasterios más durante el 
periodo colonial. ${ }^{1}$ Aunque Teresa de Cepeda y Ahumada, la religiosa reformadora de la mencionada Orden no conoció América ni la incluyó en su proyecto de expansión, las fundaciones en el Nuevo Mundo fructificaron. ${ }^{2}$ El éxito de esta naciente orden se debió a la apremiante necesidad de instaurar nuevos institutos que brindaran seguridad a mujeres espańolas y criollas dado que hasta el momento sólo se contaba con dos monasterios en la ciudad. ${ }^{3}$ Aunado a esto, estuvo el reconocimiento de la impronta del carisma observante de esta novedosa rama del Carmelo. Ésta brindaba una opción diferente de enclaustramiento conocido hasta entonces en el mundo occidental; éste se basó en el estricto seguimiento de dos de las directrices más importantes del catolicismo mendicante: la pobreza y la clausura.

El inicio del funcionamiento de este cenobio no fue sencillo ya que las fundadoras requirieron de bienhechores que brindaran apoyo tanto material como espiritual para que se lograra el debido arraigo de su Orden en Nueva España. Entre las muestras de solidaridad que recibieron estas religiosas cuando iniciaban su vida claustral en Puebla, se encontraba una reliquia significativa por su origen. Se trataba de un pequeño pedazo de carne del brazo de Teresa de Jesús. Fue sobre este resto humano que en 1618 las monjas experimentaron visiones y apariciones, las cuales una vez transcritas, generaron un documento de 22 folios, que es el motivo de este estudio. ${ }^{4}$ Estas

\footnotetext{
${ }^{1}$ Con excepción de Santa Teresa la Antigua que procedió de la iniciativa de tres religiosas procedentes del convento Real de Jesús María, al respecto puede verse a María Concepción Amerlinck y Manuel Ramos Medina, Conventos de monjas. Fundaciones en el México virreinal (México: Condumex, 1995), 103-108.

${ }^{2}$ Teresa Sánchez de Cepeda Dávila y Ahumada, aunque generalmente usó el nombre de Teresa de Ahumada hasta que comenzó la Reforma, cambiando entonces su nombre por Teresa de Jesús. Nació en Ávila el 28 de marzo de 1515 y murió en Alba de Tornés el 4 de octubre de 1582. Fue beatificada el 4 de abril de 1614 y canonizada el 12 de marzo de 1622 .

${ }^{3} \mathrm{Al}$ momento sólo existían en Puebla; el convento de Santa Catalina de Sena fundado en 1568 y el de la Purísima Concepción en 1593. Al respecto puede verse Rosalva Loreto López, Los conventos de mujeres en el mundo urbano de la Puebla de los Ángeles del siglo XVIII (México: El Colegio de México, 2000).

4 "Relación de lo que pasó en el convento de las Madres carmelitas descalzas de San José de la ciudad de los Ángeles con un pedacito de carne del tamaño de una uña de la mano de la carne de nuestra Santa Madre Teresa de Jesús", f. 1, Archivo del Convento de Santa Teresa de Puebla, en adelante ACSTP. Este documento fue transcrito a lo largo de
} 
descripciones fueron expresión de una religiosidad que fomentaba la emergencia de exaltadas expresiones devocionales. Si bien es cierto que estas siguieron los cánones y prácticas establecidas por Trento, también se deben considerar sus posibles giros interpretativos individuales.

Este manuscrito conventual, al igual que los diarios espirituales, las autobiografías, las epístolas, los poemas o los villancicos, formó parte de la cultura escrita, de la historia del libro y de la historia del monacato hispanoamericano. ${ }^{5}$ Resulta excepcional por su diseño, intención e importancia. Se trató de un texto conformado a partir de la escritura de las experiencias visionarias individuales, la intención de su factura tuvo que ver con la necesidad de consolidar un sentido

1618 por Melchora de la Asunción, quien era subpriora en el momento del histórico acontecimiento. Ella recogió los testimonios de 16 religiosas y conformó a manera de un pequeño cuaderno escrito por ambas caras en folios de $28 \times 21 \mathrm{~cm}$ aproximadamente. Posteriormente fue conocido y publicado por el maestro Eduardo Báez Macías, como parte del volumen titulado Fray Agustín de la Madre de Dios, Tesoro escondido del Monte Carmelo Mexicano (México: unAM, 1986).

${ }^{5}$ A través de numerosos estudios se ha abordado, desde la perspectiva histórica, el aporte de las monjas a la cultura escrita, al respecto véanse Asunción Lavrin: "Espiritualidad en el claustro novohispano del siglo xviı", Colonial Latin American Review 4(2) (1995): 155-180; “De su puño y letra: Epístolas conventuales”, en El monacato femenino en el imperio español, ed. Manuel Ramos Medina, 43-59 (México: Condumex, 1995); "La celda y el siglo. Epístolas conventuales", en Mujer y cultura en la Colonia hispanoamericana, ed. Mabel Moraña, 139-159 (Pittsburg: Instituto Internacional de Literatura Iberoamericana, University of Pittsburg, 1996). De manera más específica se han comenzado a editar libros colectivos que incluyen problemáticas comunes a la escritura femenina en Hispanoamérica, la conjunción de testimonios manuscritos de mujeres en clausura muestra la importancia del papel de las monjas y beatas en el desarrollo de diversos géneros literarios, al respecto véase Asunción Lavrin y Rosalva Loreto, Monjas y beatas, La escritura femenina en la espiritualidad barroca novohispana. Siglos XVII y XVIII (México: Universidad de las Américas, Archivo General de la Nación, 2002) y Diálogos espirituales. Manuscritos femeninos hispanoamericanos. Siglos XVI-XIX (Puebla: Universidad de las Américas, Instituto de Ciencias Sociales y Humanidades de la Universidad Autónoma de Puebla, 2006). De manera paralela esta tendencia ha cobrado fuerza para el caso europeo. Enfocándose en el análisis de los diversos usos de la hagiografía monástica, León Carlos Álvarez Santaló ha publicado Dechado barroco del imaginario moderno (Espańa: Universidad de Sevilla, Secretariado de Publicaciones de la Universidad de Sevilla, 2010); Nieves Baranda Leturio y María del Carmen Marín Piña, Letras en la celda. Cultura escrita de los conventos femeninos en la España moderna (Madrid y Frankfurt: Iberoamericana-Vervuert, 2014). Estas académicas se han dado a la tarea de editar un conjunto de trabajos en torno a la escritura claustral en Iberoamérica. 
de pertenencia e identidad de las primeras carmelitas con la Santa fundadora de la Orden y con sus hermanas de religión en España.

En esta comunicación proponemos analizar el papel de las narraciones generadas por las religiosas a partir de la llegada de la reliquia al convento. De manera general, puede considerase este documento como una de las más tempranas manifestaciones de la espiritualidad de la primera comunidad carmelita en América. Como primer acercamiento estableceremos el orden de las apariciones y su asociación con las advocaciones conocidas por las religiosas involucradas. Esto sugiere considerar al texto como parte de un ejercicio nemotécnico selectivo étnica y culturalmente a través del cual expresaron las monjas las necesidades sociales de identidad y cohesión de su naciente comunidad. ${ }^{6}$ Otra idea por desarrollar es la consideración de este documento como un temprano ejemplo del diseño de un texto de estética comunicativa propia de la modernidad. ${ }^{7}$ En éste es posible, gracias a las detalladas descripciones de las monjas, identificar el apego al esquema devocional tridentino y su cercanía con los cánones de la plástica y la cultura propios del barroco hispanoamericano. ${ }^{8}$ Escenas y personajes emergieron y reforzaron públicamente las

${ }^{6}$ Se conoce como nemotecnia el ejercicio mental de asociar palabras con objetos o sucesos. Ésta fue ampliamente utilizada como método devocional en los ejercicios de San Ignacio. Para el caso que aquí nos ocupa se explicitó a partir de una asociación entre advocación, iconografía y texto. Al respecto puede verse el clásico trabajo de Erwin Panofsky, Estudios sobre iconología (Madrid: Alianza, 2008).

${ }^{7}$ Retomamos el concepto de la estética como una de las posibles respuestas a la expresión figurativa de la experiencia mística. De manera más amplia esta idea de concebir a la estética como práctica de control cultural puede verse en David Freedberg, El poder de las imágenes, estudios sobre la historia y la teoria de la respuesta, Arte, Grandes temas (Madrid: Catedra, 1992). De manera más específica se debe consultar a Víctor I. Stoichita, El ojo mistico. Pintura y visión religiosa en el Siglo de Oro español (Madrid: Alianza Forma, 1996) y a Ernst Gombrich, Los usos de las imágenes. Estudio sobre la función social del arte y la comunicación visual (México: Fondo de Cultura Económica, 2003).

${ }^{8}$ Se reconoce al barroco como una tendencia cultural desarrollada en el mundo occidental entre 1600 y 1750 . De manera tradicional se le reconoce como un periodo en la historia de la cultura que desde diferentes contextos generó una novedosa manera de concebir el arte impactando en sus diversos campos. De manera específica y en el caso que nos concierne, en la historia de la escritura que se desarrolló como una práctica cultural difundida en el ámbito claustral femenino. $\mathrm{Al}$ igual que la pintura y la escultura, el arte de escribir adquirió características específicas a través de narraciones, experiencias y expresiones propias de la mística. De manera paralela estos elementos fueron recreados 
propuestas del cristocentrismo, la mariología, de los elementos más conocidos para ellas del Nuevo Testamento y del santoral de su Orden. En la relación de las imágenes y los textos fue posible atisbar algunos visos de una sensibilidad femenina que se construyó, en este caso, de manera extraordinaria dentro de la comunidad monástica. Estos elementos estuvieron asociados con la modernidad emocional aportada por los esquemas teológicos y ascéticos y, por esta razón, en una tercera parte trataremos de identificar la utilización de los textos descritos como medios de expresión de regímenes emocionales que les permitieron expresar sus necesidades emotivas y sus afectos.

\section{LA COMUNIDAD DE CARMELITAS DESCALZAS,}

\section{LA RELIQUIA Y EL TEXTO}

Hacia 1615, el monasterio carmelita de señor San José ya estaba en funcionamiento. Las fundadoras habían experimentado dos traslados para llegar finalmente al que sería su convento definitivo a lo largo de los siguientes siglos. Primero habían intentado sobrevivir organizadas como beatas en el puerto de Veracruz, pero dadas las inclemencias del clima, lo inseguro del puerto y en atención a las recomendaciones de los conciliares, los jesuitas que las asistían sugirieron su cambio a la ciudad de Puebla de los Ángeles. Estos religiosos promovieron que el ayuntamiento local les donara unos terrenos a la entrada del camino que salía de la Angelópolis hacia la ciudad de Cholula. La casa conventual quedaba anexa a las construcciones jesuitas que en ese momento se estaban erigiendo; la capilla de San Idelfonso y la iglesia parroquial de San Marcos. La inseguridad y la lejanía continuaba siendo una preocupación latente y gracias a la vinculación con los carmelitas radicados en Puebla se promovió y

en la pintura y en la escultura mediante efectos, ilusiones plásticas y estéticas, con efectos forzados y violentos, fuertes contrastes de luces y sombras y cierta tendencia al desequilibrio y la exageración. Antonio Martínez Ripoll, El barroco en Europa, Historia 16 (Madrid: Historia Viva, 1999); Étienne Souriau, Diccionario Akal de Estética (Madrid: Akal, 1998). De manera concreta la interpretación de la mística en el universo de la escritura barroca española puede constatarse con el trabajo de C. Álvarez Santaló con su Dechado barroco. 
facilitó su traslado hacia su nuevo sitio, en una de las principales calles de la ciudad, en unos terrenos cercanos al río de San Francisco. El afluente servía de barrera social, pues, dividía físicamente la ocupación de las dos repúblicas étnicamente establecidas, la de españoles y la de indios. En 1604, cuando se realizó el traslado y poblamiento del actual monasterio, el edificio aún se encontraba con oficinas muy precarias y sencillas, la barda que lo delimitaba aún no estaba terminada y las 18 religiosas que lo habitaban experimentaban cotidianamente miedo, temores y zozobras dadas sus limitaciones económicas. Para su auxilio espiritual dependieron de los religiosos carmelitas que regularmente las confesaban y aconsejaban. El 28 de agosto de 1618, las religiosas recibieron en su sencillo locutorio la visita de fray José de Jesús María, a la sazón padre general de la provincia del Santo Desierto en la Nueva España. El traía consigo un fragmento de carne de Teresa de Jesús, era del tamaño de una uña y se transportaba adecuadamente envuelto en tafetán dorado. Varias intenciones se dejan ver en este valioso obsequio. Retomando la experiencia de la taumaturgia tardo medieval, con la presencia de la reliquia se buscaba una identificación de las carmelitas en América con su fundadora y con los monasterios peninsulares. Con esto se buscaba el reconocimiento social del convento en el ámbito urbano a la vez que se cubría la necesidad de convalidación externa por parte del resto de los miembros de la corporación eclesiástica. Confesores, directores espirituales y los representantes del clero secular se vieron de diversas maneras involucrados en el suceso.?

Las religiosas esperaban que dicha reliquia tuviera los mismos atributos otorgados a los restos de Juan de la Cruz y a las de santa Teresa en Europa. Éstos consistían en fomentar milagrosas apariciones en quienes la observaban con detenimiento. ${ }^{10}$ Ellas, al recibir el

\footnotetext{
${ }^{9}$ Aunque siempre estuvieron presentes los carmelitas como guías espirituales de sus hermanas de religión, su papel siempre estuvo mediado por el obispo. Se han documentado varios intentos legales por parte de los carmelitas de poner bajo su administración a los conventos de religiosas. Al respecto véase Ramos Medina Manuel, Misticas y descalzas (México: Universidad Iberoamericana, 1990).

${ }^{10}$ En coincidencia con Asunción Lavrin se puede considerar, como parte importante del carisma teresiano además de la oración, la obediencia y la pobreza, a las prácticas visionarias enmarcadas por milagros, prodigios, éxtasis, revelaciones, visiones y favores de
} 
maravilloso regalo expresaron regocijo a la vez que un cierto resentimiento, pues,

Nunca su Santa Madre había en esta casa obrado algunas de las maravillas que [hace] en España. Atribuyendo esto a sus deméritos ya que no eran verdaderas hijas suyas. Hubo algunas que dijeron que mirasen la reliquia de la santa para ver si por ventura les hacía Nuestro Señor la [misma] merced que en España. ${ }^{11}$

La queja cobraba sentido si consideramos que esta fundación, como la mayoría de las realizadas en el Nuevo Mundo, dependieron, salvo contadas excepciones, de la iniciativa de mujeres que por orfandad, viudez o vocación tardía habían decidido agruparse en un beaterio o recogimiento para sobrevivir. ${ }^{12}$ Se trataba de una fundación de nuevo cuño, auspiciada por los regulares, pero carentes de un modelo de implantación directa de la Península. ${ }^{13}$ La presencia de la reliquia venía, por un lado, a fortalecer la cercanía con sus hermanas de religión localizadas al otro lado del Atlántico; y, por otro, a incentivar la taumaturgia milagrosa de lograr la fecundidad, la sanación y la salvación de los miembros de la comunidad monástica, milagros que, según lo descrito en el documento, también podían obrarse en el Nuevo Mundo.

Dios. Éstas constituyeron una de las herencias más importantes a la cultura femenina novohispana, de hecho, la autora considera a este conjunto de manifestaciones como un método que se adaptó a las necesidades emocionales de las intérpretes. Véase, Ángela Atienza López, "Santa Teresa en los conventos de monjas de Nueva España", Hispania Sacra, LXVII (136) (2015): 511.

${ }^{11}$ Archivo del Convento de Santa Teresa de Puebla (ACSTP), "Relación de lo que paso en el convento", f. 1.

${ }^{12}$ Se puede hablar de varios modelos de fundaciones conventuales en Nueva España, el más recurrido procede de iniciales beaterios o recogimientos, bajo esta modalidad iniciaron su vida de clausura voluntaria y votos temporales 11 de las 57 fundaciones conventuales. Al respecto puede verse Rosalva Loreto López, "La función social y urbana del monacato femenino novohispano", en La Iglesia en Nueva España. Problemas y perspectivas de Investigación, coord. María del Pilar Martínez López Cano, 237-266 (México: UNAM, 2010).

${ }^{13}$ Mientras en Espańa, bajo la iniciativa de Teresa de Jesús se fundaron 17 monasterios reformados, en la Nueva Espańa la iniciativa partió de seglares ajenas a la Orden. 


\section{LA RELIQUIA}

El culto de las reliquias aparece como uno de los elementos distintivos desde tempranas épocas del catolicismo. En cuanto se reconocía canónicamente la notable virtud del personaje, daba inicio el proceso de autorización por parte de la Sagrada Congregación de ritos en Roma para introducir la causa y buscar su santificación, se sumaba a esto la propagación de culto hacia el futuro santo. Los restos de los mártires y santos adquirían un valor material y espiritual especial, dado que se consideraban receptáculos de lo sagrado. Para las órdenes religiosas y, en especial, para los conventos que gozaban la fortuna de poseer alguna, el cuerpo del bienaventurado se convertía en una marca identitaria que asociaba ese sagrado elemento orgánico con la santa mujer y con el convento. ${ }^{14}$ De manera metafórica, la comunidad poseedora de una reliquia, se regeneraría sin cesar. Los restos corporales santificados sirvieron de base para afianzar y difundir valores comunes derivados de una misma concepción religiosa. ${ }^{15}$ Tampoco debemos olvidar que su posesión era también sinónimo

${ }^{14}$ La propuesta identitaria como un aporte percibido a través de la vida de Santa Teresa la ha desarrollado para el caso español Ángela Atienza López, "En permanente construcción. La recreación de la figura de Santa Teresa en las semblanzas biográficas de sus hijas", Hispania Sacra LXvII(136) (2015): 581.

${ }^{15}$ Una primera problemática al respecto abordaría el papel de la reliquia-cuerpo, un acercamiento fue hecho por Jacques Le Goff, “¿La cabeza o el corazón?’ El uso político de la metáforas corporales durante la edad media”, en Fragmentos para una historia del cuerpo humano, parte tercera, Michel Feher et al., 12-26 (Madrid: Taurus, 1990); Christian William, Apariciones en Castilla y Cataluña (siglos XIV-XVI) (Madrid: Nerea, 1990); Jacques Gélis, "El cuerpo, la Iglesia y lo sagrado", en Historia del cuerpo, Renacimiento a la Ilustración, vol. 1, dir. Georges Vigarello, 85 (Espańa: Taurus, 2005). De manera concreta para el caso mexicano puede consultarse Michael De Stefano, "Miracles and Monasticism in Mind-Colonial Puebla, 1600-1750: Charismatic Religion in a Conservative Society" (Tesis de doctorado, University of Florida, 1977); Antonio Rubial, "Los santos milagreros y malogrados de la Nueva España", en Manifestaciones religiosas en el mundo colonial americano, vol. I, coord. Clara García Ayluardo y Manuel Ramos Medina, 71-105 (México: Condumex, INAH, Universidad Iberoamericana, 1993); Gabriela Sánchez Reyes, "Relicarios Novohispanos a través de una muestra de los siglos Xvi al xvıII" (Tesis de maestría en Historia del Arte Colonial, FFyL-unam, 2004); Antonio Rubial García, "Cuerpos milagrosos. Creación y culto de las reliquias novohispanas", Estudios de Historia Novohispana (18) (1998): 3-30; William B. Taylor, Marvels and Miracles in Late Colonial Mexico. Three Texts in Context (Albuquerque: University of New Mexico Press, 2011). 
de salvaguarda emocional en sociedades vulnerables y sujetas a los avatares de la naturaleza. La presencia de la reliquia se constituyó en un elemento de cohesión social dentro del monasterio, pues en torno a una figura tutelar 16 religiosas coincidieron en experimentar visiones.

En el caso que aquí presentamos, el pedacito de carne de la entonces beata Teresa de Ávila, les fue entregado solemnemente con el ánimo de compartir la veneración que en España ya existía hacia la futura Santa. Resulta significativo que en Europa los restos de los que más tarde se reconocerían como mártires y santos carmelitas, comenzaron a circular tan pronto éstos murieron. ${ }^{16}$ En el caso de Teresa de Jesús se trató específicamente de una reliquia privada, que circuló entre los superiores de la Orden, entre reconocidos y ancianos frailes o entre confesores contemporáneos de la insigne mujer. Se trató de un pedazo muy pequeño de la carne de su brazo. ${ }^{17}$ Esta condición no era excepcional, pues, la mayoría de las reliquias de los santos eran fragmentarias, raramente se conservaban cadáveres completos. ${ }^{18}$ Esta condición no afectaba en absoluto la conciencia

${ }^{16}$ Llama la atención que se equipararan las capacidades taumatúrgicas de las dos reliquias dado que Juan de la Cruz aún no estaba canonizado y tenía las limitaciones de Non culto recomendadas por la Sagrada Congregación de Ritos en el Vaticano hasta que no se efectuara su beatificación. Juan de Yepes o fray Juan de la Cruz nació el 24 de junio de 1542 en Ávila y murió el 14 de diciembre de 1591. Fue beatificado el 25 de enero de 1675 y se canonizó el 27 de diciembre de 1726.

${ }^{17}$ Una versión de la procedencia orgánica de la reliquia es manejada por el fraile Agustín de la Madre de Dios, publicado por Báez Macías, Tesoro Escondido, 316. Este religioso reinterpretó el documento original escrito por la religiosa Melchora de la Asunción, del cual se encuentra el original en el Archivo del Convento de Santa Teresa de Puebla (ACSTP). En varias ocasiones su transcripción altera el contenido, en este caso, atribuye el origen de la reliquia a un pedazo del corazón de la Santa de Ávila. Omitiendo las dos posibilidades del acontecimiento original. Una primera procedencia puede ser atribuida al resultado de la primera exhumación en la que participó el padre fray Jerónimo Gracián, amigo de la Santa en 1582, el religioso le cortó la mano izquierda y un dedo meñique. Otro posible origen alude al brazo reliquia que permaneció en el convento donde murió la santa después del robo realizado por el padre Gregorio Nacianceno y otros monjes de Ávila en 1585. Jacques Gélis, "El cuerpo, la Iglesia y lo sagrado" en Historia del cuerpo, Renacimiento a la Ilustración, vol. 1, dir. Georges Vigarello, $96-97$ (España: Taurus, 2005).

${ }^{18}$ Cabe aclarar que de manera particular en Puebla durante la primera mitad del siglo XviI se contaba con dos cuerpos presumiblemente incorruptos. El primero corres- 
religiosa, pues, cada fragmento era capaz de conservar la carga sagrada originaria, en este caso, dada la lejanía y la importancia de la reliquia, la parte valía tanto como el todo. El éxito de su culto, se basó en suponer posibles transferencias de los atributos sagrados del cuerpo de la Santa a sus devotas hermanas de religión.

El fragmento donado a las carmelitas resultaba informe, pero por cuestiones "de la naturaleza" comenzó a asimilarse a la forma de un dedo y a venerarse como tal. Si bien es cierto que los dedos-reliquias fueron menos numerosos que los brazos, existían antecedentes de su popularidad en Europa. Su importancia procedía de las asociaciones iconográficas que se generaban en el poder de la extremidad, por ejemplo, en la pintura de san Juan Bautista anunciando la venida del Mesías, el santo aparece con el dedo apuntando hacia el cielo. ${ }^{19} \mathrm{O}$ en ocasiones, el dedo del mismo santo seńala la herida del costado de Cristo, escena que lo dotaba de validación teológica de la imagen de las cinco llagas. ${ }^{20}$ Cabe aclarar que la reliquia en cuestión conservó entre sus características la mutabilidad de la forma pues en ocasiones

pondía al fraile franciscano fray Sebastián de Aparicio (1502-1680), beatificado el 17 de mayo de 1789. Al respecto véase a Pierre Ragon, "Sebastián de Aparicio. Un santo mediterráneo en el altiplano mexicano", Estudios de Historia Novohispana (23) (2000): 17-46. El otro caso es el de la religiosa concepcionista sor María de Jesús (1579-1637). De ella se conoce un primer intento de introducir la causa de beatificación ante la Sagrada Congregación de Ritos del Vaticano por el entonces obispo de Puebla Juan de Palafox, realizándose una primera exhumación en 1646. Su intento fracasó debido a que la religiosa aún no había cumplido los 10 años de sepultada, requisito necesario para comprobar la incorruptibilidad. Fue el obispo Diego Osorio de Escobar y Llamas, quien propiamente ordenó el proceso informativo en 1661 y lo envió al papa Clemente, quien nombró ponente de la Causa ante la Sagrada Congregación de Ritos del Vaticano al cardenal Gaspare Carpegna. Al respecto puede verse Rosalva Loreto López, "Las pruebas del milagro en el proceso de beatificación de la Madre María de Jesús", en Historia de la Iglesia en el siglo XIX (México: El Colegio de México, El Colegio de Michoacán, Instituto Mora, UAM-Iztapalapa, Condumex, 1998), 351-369.

${ }^{19}$ Se encuentran ejemplos de conservación de dedos-relicarios de los santos Santiago el Mayor en Mesina, santo Tomas de Aquino en Bolonia, san Teobaldo en Thann, santo Domingo en Múnich, santa Gertrudis en Bamberg, santa Isabel en Heilbronn, santa María Magdalena en Venecia y otros muchos. "Fingerreliquiar", en Reallexicon zur deutschen Kunstgeschichte, t. viII, cols. 1,207-1,223 (Munich: 1987), citado por Jacques Gélis, "El cuerpo, la Iglesia y lo sagrado", 86.

${ }^{20}$ Esta escena de la Crucifixión está representada en los dos paneles centrales del Retablo de Isemhein del pintor alemán Matthias Grnewald a manera de retablo elaborado entre los años 1512 y 1516. Museo de Unterlinden, Colmar, Francia. 
se asimilaba a una falange y por momentos se comportaba, según las religiosas escrutadoras, como un segmento de carne viva.

El origen de la reliquia aunque incierto, se asoció con el trozo de carne arrancado de la mano izquierda de la Santa por el padre Gracián dado que en su relato el sacerdote describió:

me lleve esa mano en una funda envuelta además en papel, y destiló aceite [...] la deje en Ávila en una arca cerrada [...] cuando corté la mano, también corte un meñique que llevo siempre encima [...] durante mi cautiverio, los turcos me lo quitaron y lo rescate por unos veinte reales y anillos de oro. ${ }^{21}$

Hacia 1617 se realizó la casi obligada visita del padre general de la Orden, fray José de Jesús María al sepulcro de la Santa en Alba de Tormes. Ahí, en el monasterio de las madres carmelitas de la Anunciación, el religioso adquirió un fragmento de su segmentado cuerpo y lo transportó consigo pensando en las religiosas poblanas. $\mathrm{Su}$ depósito en el claustro fue motivo de orgullo para la ciudad y para la hermandad conventual. Resultaba un privilegio poseerla, pues, sólo a los grandes personajes les estaba permitido tener estos santos fragmentos. Se trataba de una cultura donde tocar y mirar equivalía a comprobar y en la que resultaba muy importante el contacto directo con el cuerpo del otro, aunque éste estuviese muerto.

Una vez en posesión de la reliquia, a las religiosas les surgió el deseo de establecer un acercamiento íntimo con el sagrado pedacito de carne, en la soledad de su celda la observaron con detenimiento en espera de alguna señal divina y una a una fue observándola. A este conjunto de mujeres, de manera excepcional les fue permitido vivir de cerca y transitoriamente el proceso del iluminismo como parte de una experiencia mística. ${ }^{22}$ Este ejercicio individual permitió

${ }^{21}$ Jacques Gélis, "El cuerpo, la Iglesia y lo sagrado”, 87.

${ }^{22}$ Las monjas visionarias son aquellas mujeres que dotadas de la Gracia Divina han pasado por los estadios previos de purificación. Al momento de pasar al estadio final del iluminismo, antes de alcanzar la vida de perfección, Dios se comunica con ellas mediante visiones y locuciones. Al respecto puede verse Ad. Tanquerey, Compendio de teología ascética y mistica (Roma: Sociedad de San Juan Evangelista, 1930). 
a las religiosas fundadoras que fungieron como testigos de cada narración, aseverar que, en efecto, se trataba de un acontecimiento que permitía compartir la santidad al interior de su comunidad. Verbalizar las visiones, describirlas y, sobre todo, escribirlas fue una acción casi obligada, pues, su lectura por parte de las autoridades permitía, en caso de ser necesario aplicar filtros para evitar peligrosas confusiones entre prácticas mágicas y los ritos sagrados. Ellas estaban conscientes de ese riesgo y manifestaron esta preocupación:

Cuando comenzaron estas pariciones se han ofrecido muchas horas de oración mental, muchas comuniones y sacrificios suplicando a Nuestro seńor que si esta causa no era suya fuese servido de que cesasen estas visiones y que no permitiese [...] que cayésemos en alguna ilusión o error del demonio. $^{23}$

Las apariciones también estuvieron sujetas a escrutinio social, pues, éstas fueron experimentadas y relatadas por las monjas fundadoras, todas de origen espańol y una criolla, quienes desempeńaron cargos en la comunidad a lo largo de los primeros 14 años de vida del monasterio. ${ }^{24}$ El día 29 de agosto de dicho año, día de la degollación de san Juan Bautista, ${ }^{25}$ estando la madre Elvira de San José en su celda y "movida por la curiosidad" observó con atención la reliquia, esperando con verdadera devoción que se hiciera el milagro de la que sería la primera aparición. ${ }^{26}$ Ella logró identificar el rostro de Teresa

${ }^{23}$ ACSTP, "Relación de lo que pasó en el convento", f. 10.

${ }^{24}$ De la primera de carmelitas en Puebla, compuesta por 18 monjas de velo negro y coro que estuvieron presentes en el evento de la reliquia sólo quedaron excluidas las hermanas legas que tomaron el velo blanco para "frailas": María de San Francisco y la negrita Juana de la Esperanza que ingresó al monasterio como esclava.

${ }^{25}$ El día de agosto de la primera aparición no fue casual del todo si aludimos a los atributos del Santo como profeta que anunció con antelación la llegada de Jesús. Posteriormente al bautizarlo en el río Jordán dio inicio un nuevo ciclo en la historia de la cristiandad al asociar este rito como Sacramento. En este sentido puede asimilarse la llegada de la reliquia con el inicio de una nueva historia para la comunidad carmelitana en el Nuevo Mundo.

${ }^{26}$ Elvira de San José, llevo por nombre del siglo Elvira de Suárez y Díaz. Originaria de la ciudad de Cuenca, hija de padres sevillanos, pasó al Nuevo Mundo junto con su esposo y un niño de pecho, muriendo estos dos últimos en Veracruz. Contaba esta mujer 
de Jesú $s^{27}$ y lo comunicó a la priora Francisca de la Natividad, quien se encontraba en compañía de otras religiosas. ${ }^{28}$ En principio, casi todas se mostraron escépticas, aludiendo que, Elvira por su gran emoción, veía a la imagen descrita pero esta sólo se le había representado en la imaginación. ${ }^{29} \mathrm{O}$ lo que era lo mismo la había visto con los ojos del alma. ${ }^{30}$ Más adelante Elvira continuó con su atenta observación y distinguió que entre "unos hilitos de oro que estaban atravesados en la santa carne [...] de repente salía un rostro en la carne como si fuera iluminado, se trató de un varón con barba blanca y tan distinto y claro como si fuera pintado". ${ }^{31}$

Ante la insistencia de la religiosa, la priora convocó a la subpriora, a la maestra de novicias y a las religiosas más "antiguas", para realizar, ya de manera formal, un primer escrutinio del santo fragmento. A partir de entonces, las otras monjas la tuvieron en su mano y en la quietud de su celda la escudriñaron repetidamente y cada una fue hablando de sus respectivas visiones, que a manera de

con 22 años cuando se unió a las otras futuras fundadoras, vivieron en el puerto 7 años y 3 de recogimiento en Puebla antes del poblamiento en su casa definitiva. Por su iniciativa al leer la vida de Santa Teresa, propuso la fundación carmelitana. Junto con dońa Ana y Beatriz Núñez de Montalbán fue una de las fundadoras. Otorgó el capital necesario que como requisito se pedía para afianzar la fundación. Este dato fue declarado en la solicitud que se envió al rey y al papa para garantizar el sustento de la comunidad. ACsTP, Primer libro de Profesiones, f. 67v.

${ }^{27}$ ACSTP, "Relación de lo que pasó en el convento", f. $1 \mathrm{v}$.

${ }^{28}$ El nombre del siglo de Francisca de la Natividad fue Francisca de Valencia Montenegro y Tapia, nació, al igual que sus progenitores, en Benalcázar en los reinos de Castilla. Pasó junto con sus hermanas a América, profesó el 13 de septiembre de 1609. Fue una de las más sobresalientes religiosas de este convento pues fue la secretaria de la madre Isabel de la Encarnación, religiosa virtuosa que mereció se escribiera y publicara su ejemplar vida. ACsTP, Primer Libro de profesiones, f. 72 . Fue 14 años tornera, por eso le llamaban "la tornera" o la "gachupina". Fue la tercera priora del convento.

${ }^{29}$ ACSTP, "Relación de lo que pasó en el convento", f. 1 .

${ }^{30}$ En este caso específico, el término se refiere a las visiones imaginarias o imaginativas que son producidas en la imaginación por Dios o por los ángeles en el estado de vigilia o durante el sueño. Así se apareció varias veces un ángel a San José. Santa Teresa cuenta muchas visiones imaginativas de la humanidad de nuestro señor estando ella despierta. Ad.Tanquerey, Compendio de teología, 954. Resulta notable la influencia de la lectura del libro Camino de Perfección de Teresa de Ávila en la justificación teológica de las visiones que experimentaron las monjas en Puebla. El texto se menciona formando parte de la librería del convento desde la fundación.

${ }^{31}$ ACSTP, "Relación de lo que pasó en el convento", f. 1. 
Cuadro i. Nombre de la religiosa y número de apariciones relatadas en 1618

\begin{tabular}{lllc}
\hline Nombre de la monja & $\begin{array}{l}\text { Fecha de } \\
\text { profesión }\end{array}$ & Origen & $\begin{array}{c}\text { Número de } \\
\text { apariciones }\end{array}$ \\
\hline Ana de la Concepción & $25-01-1614$ & Biruega & 2 \\
Catalina de Cristo & $12-08-1609$ & Sevilla & 4 \\
Elvira de San José & $27-12-1604$ & España & 10 \\
Francisca de la Natividad & $13-09-1608$ & Benalcázar, Castilla & 14 \\
Isabel de la Encarnación & $25-03-1613$ & Biruega & 11 \\
Jerónima de San Bartolomé & $23-07-1606$ & Espańa & 10 \\
Josefa de Jesús María & $05-08-1615$ & Benalcázar, Castilla & 1 \\
Juana de San Pablo & $28-12-1605$ & Sevilla & 10 \\
Luisa de San Nicolás & $10-09-1612$ & España & 1 \\
Magdalena de San Pedro & $23-03-1608$ & Toledo & 22 \\
María del Costado de Cristo & $23-03-1608$ & Toledo & 3 \\
Mariana del Sacramento & $27-07-1614$ & Cuenca & 12 \\
Marina de la Cruz & $01-09-1613$ & Castilla & 5 \\
Melchora de la Asunción & $07-08-1606$ & Asturias & 3 \\
Micaela de Santiago & $23-07-1606$ & Galicia & 12 \\
Teresa de Jesús & $05-07-1609$ & Asturias & 2 \\
\hline
\end{tabular}

Fuente: elaboración propia a partir de la transcripción paleográfica de "Relación de lo que pasó en el convento de las Madres carmelitas descalzas de San José de la ciudad de los Ángeles" y "Primer Libro de profesiones del Convento de Carmelitas Descalzas de San José y Santa Teresa", 16041730, Archivo del Convento de Santa Teresa de Puebla, ACSTP.

narraciones fueron escritas por Melchora de la Asunción. ${ }^{32}$ Todas estas monjas se encargarían de formar en las generaciones venideras una tradición específica de su orden.

El cuadro 1 muestra el nombre de las monjas relatoras y el número de apariciones experimentadas por cada una de ellas.

32 Melchora de la Asunción, en el siglo se llamó Melchora de Santa Clara González Guerrero y Mendoza, hija de padres asturianos, fue la primera criolla que profesó en el convento. Su padre aportó un importante capital para la construcción del monasterio. Desde niña vistió el hábito de San Francisco y por eso se añadió a su nombre el de Santa Clara. Ya con las carmelitas profesó el 7 de agosto de 1606, ocupó los cargos de enfermera, subpriora, maestra de novicias, vicaria y priora, cargo que ocupaba a su muerte. ACsTP, Primer Libro de Profesiones, f. 69v. 
Cabe destacar que para las fechas contenidas en el cuadro 1, las religiosas cuya profesión quedó comprendida entre 1604 y 1608 fueron consideradas como las fundadoras sobrevivientes y principales visionarias, el 2 de febrero de 1615 se completó históricamente la primera comunidad de carmelitas descalzas del Nuevo Mundo.

\section{LA REPRESENTACION Y LA MEMORIA}

Varias preguntas emergen de las descripciones de las apariciones: ¿en qué medida la memoria influyó para generar las apariciones? ¿Mantuvieron una fiel relación con las pinturas y estampas que las monjas veían cotidianamente? ¿Se trataba de una representación mental basada en la imaginación? En este texto las posibles respuestas están asociadas con una relación explicita pues casi $20 \%$ de las imágenes aludidas mencionaron su fuente de inspiración. En este sentido, se refirieron las religiosas a una imagen conocida para expresar en un discurso escrito su experiencia visionaria. Este ejercicio no resultaba del todo desconocido en el mundo occidental si partimos de la idea de que fue a través de la plástica como se expresaron las visiones. La composición de las escenas imaginadas tenían como objetivo transmitir, plasmar y hacer comprender lo que el santo sintió ante una determinada aparición, las escenas; compuestas o fragmentarias expresaron en sí mismas experiencias místicas. ${ }^{33}$ El siguiente cuadro remite a la relación de las monjas con las obras de arte conocidas por ellas.

Esta asociación entre el texto y la imagen aludida nos remite a una problemática ya estudiada desde la perspectiva de las artes visuales. Algunas aproximaciones se han enfocado en la búsqueda de las semejanzas entre las representaciones plásticas, otras se han centrado en analizar sus códigos de interpretación. ${ }^{34}$ Dada la importancia del

${ }^{33}$ Víctor I. Stoichita, El ojo mistico, 18 y 152. Para este autor cada visión representa un metadiscurso imaginario.

${ }^{34}$ Esta perspectiva puede presentarse por un doble acercamiento, por un lado, alude a los manuales de pintura de la época y a las recomendaciones tridentinas sugeridas en ellos para validar las representaciones religiosas. Por otro, resulta notable la tendencia a estudiar la historia de las ideas estéticas en relación con otras disciplinas, a manera de ejemplo contamos con la obra de Mario Praz, Mnemosyne El paralelismo entre la literatura 
Cuadro 2. Advocaciones que aluden a alguna técnica artística para su representación, 1618

\begin{tabular}{|c|c|c|}
\hline $\begin{array}{l}\text { Nombre de la } \\
\text { monja }\end{array}$ & Imagen & Técnica aludida \\
\hline \multirow[t]{6}{*}{$\begin{array}{l}\text { Melchora de la } \\
\text { Asunción }\end{array}$} & San Pedro & $\begin{array}{l}\text { Rostro en la carne como si fuera } \\
\text { iluminado, de varón con barba blanca } \\
\text { como si fuera pintado, f. } 1 \mathrm{v}\end{array}$ \\
\hline & Cristo & $\begin{array}{l}\text { De la suerte que le pintan cuando } \\
\text { oraba en el huerto, f. } 4\end{array}$ \\
\hline & $\begin{array}{l}\text { Oración del } \\
\text { Huerto }\end{array}$ & $\begin{array}{l}\text { Vio a los apóstoles como los pintan } \\
\text { durmiendo en el huerto, f. } 4\end{array}$ \\
\hline & Virgen y san Juan & $\begin{array}{l}\text { Del modo en que los pintan junto a } \\
\text { la cruz, f. } 5\end{array}$ \\
\hline & Santa Verónica & $\begin{array}{l}\text { El rostro del Señor a la manera que } \\
\text { pintan este paso, f. } 5\end{array}$ \\
\hline & San Ángel & $\begin{array}{l}\text { Sobre la cabeza atravesado un cuchillo } \\
\text { dorado a la manera que pintan al } \\
\text { glorioso mártir, f. } 5\end{array}$ \\
\hline \multirow[t]{2}{*}{$\begin{array}{l}\text { Francisca de la } \\
\text { Natividad }\end{array}$} & Santa Teresa & $\begin{array}{l}\text {...al modo que pintan cuando quie- } \\
\text { ren figurar un alma, f. } 2\end{array}$ \\
\hline & $\begin{array}{l}\text { Fray Juan de la } \\
\text { Cruz }\end{array}$ & $\begin{array}{l}\text { Que por la estampa que anda del } \\
\text { santo conoció que era él, f. } 2 \text {. }\end{array}$ \\
\hline \multirow[t]{4}{*}{$\begin{array}{l}\text { Juana de } \\
\text { San Pablo }\end{array}$} & Cristo & $\begin{array}{l}\text { De la misma manera que cuando está } \\
\text { una figura impresa en un Agnus de } \\
\text { Cera, f. } 3 \text {. }\end{array}$ \\
\hline & Santa Verónica & $\begin{array}{l}\text { El rostro del Señor cae sobre su pecho } \\
\text { a la manera que pintan este paso, f. } 3 \text {. }\end{array}$ \\
\hline & $\begin{array}{l}\text { San Juan } \\
\text { Bautista }\end{array}$ & Como le pintan en el bautismo, f. $3 \mathrm{v}$ \\
\hline & Padre Eterno & Según la pintura ordinaria, $\mathrm{f} 5 \mathrm{v}$ \\
\hline $\begin{array}{l}\text { Micaela de San- } \\
\text { tiago }\end{array}$ & Santa Verónica & $\begin{array}{l}\text { El rostro del Señor a la manera que } \\
\text { lo pintan }\end{array}$ \\
\hline \multirow[t]{2}{*}{$\begin{array}{l}\text { Mariana del } \\
\text { Sacramento }\end{array}$} & $\begin{array}{l}\text { Rostro de Cristo } \\
\text { con la mano en } \\
\text { la mejilla }\end{array}$ & $\begin{array}{l}\text { Muy afligido a la manera en que lo } \\
\text { pintan en el Calvario, f. } 7 v\end{array}$ \\
\hline & $\begin{array}{l}\text { Oración del } \\
\text { Huerto }\end{array}$ & $\begin{array}{l}\text { Vio los árboles y en lo alto el ángel } \\
\text { como lo suelen pintar, } \mathrm{f} .7 \mathrm{v}\end{array}$ \\
\hline $\begin{array}{l}\text { Catalina de San } \\
\text { José }\end{array}$ & $\begin{array}{l}\text { Oración del } \\
\text { Huerto }\end{array}$ & $\begin{array}{l}\text { Vio a nuestro Señor cuando le pintan } \\
\text { en medio del [campo] inclinado o } \\
\text { postrado, f. } 8 \text {. }\end{array}$ \\
\hline
\end{tabular}


Cuadro 2. Advocaciones que aluden a alguna técnica artística para su representación, 1618 (continuación)

\begin{tabular}{|c|c|c|}
\hline $\begin{array}{l}\text { Nombre de la } \\
\text { monja }\end{array}$ & Imagen & Técnica aludida \\
\hline $\begin{array}{l}\text { Luisa de San } \\
\text { Nicolás }\end{array}$ & Judas & $\begin{array}{l}\text { Vio a cristo con cuerpo entero y un } \\
\text { hombre que le daba un beso como } \\
\text { pintan a Judas, } f .8 v\end{array}$ \\
\hline \multirow[t]{4}{*}{$\begin{array}{l}\text { Magdalena de San } \\
\text { Pedro }\end{array}$} & San Jerónimo & $\begin{array}{l}\text { Con su león con barba entre cana y } \\
\text { muy larga, vestido como lo pintan, } \\
\text { f. } 9 \mathrm{v}\end{array}$ \\
\hline & $\begin{array}{l}\text { San Juan Evange- } \\
\text { lista y a la Virgen }\end{array}$ & $\begin{array}{l}\text { A la manera como los pintan al pie de } \\
\text { la cruz, } f \text {, 9v. }\end{array}$ \\
\hline & $\begin{array}{l}\text { San Juan de la } \\
\text { Cruz }\end{array}$ & $\begin{array}{l}\text { Conoce que es este santo porque es } \\
\text { muy conforme a los que traen ahora } \\
\text { pintados en estampas de España, f. } 9 \mathrm{v}\end{array}$ \\
\hline & San Juan Bautista & $\begin{array}{l}\text { Como lo pintan bautizándolo (a } \\
\text { Cristo) f. 10v }\end{array}$ \\
\hline
\end{tabular}

Fuente: Elaboración propia con base en la "Relación de lo que pasó en el convento de las Madres carmelitas descalzas de San José de la ciudad de los Ángeles", ACSTP.

camino sugerido en el documento histórico aquí trabajado, nos aproximaremos a su comprensión desde la perspectiva de la práctica de la analogía que permitió asociar el imaginario y las obras conocidas. ${ }^{35}$

San Agustín en sus Confesiones trató expresamente la importancia de la memoria y la consideró como parte fundamental del alma humana. ${ }^{36}$ Para el santo, lo que en ésta se almacenaba "no son las

y las artes visuales (Madrid: Taurus, 1979). Otra aproximación depende de buscar las coincidencias entre la obra de arte y la cultura específica de su tiempo. De manera más concreta para el periodo que nos ocupa contamos con la inspiradora obra de Stoichita, $E l$ ojo mistico, en este texto se percibe la intención de mostrar las interpretaciones que los artistas espańoles dieron a las directrices del oficio e hicieron suyas, mediante el proceso creativo, las manifestaciones del misticismo del barroco.

${ }^{35}$ Junto con el motivo de la representación, el paisaje de fondo y los elementos iconográficos se conformaron unidades culturales identificables. En este proceder, la pintura flamenca desempeńó un papel fundamental en el arte renacentista. Véase Ernst $\mathrm{H}$. Gombrich, Norma y forma (Madrid: Alianza Forma, 1984), 227-248.

${ }^{36}$ San Agustín de Hipona, Confesiones, x, 8, 12, x, 28, 30, 399-425, Citado por Linda Báez Rubí, Mnemosine novohispánica. Retórica e imágenes en el siglo XVI (México: UNAM, IIE, 2005), 28. 
cosas, sino las imágenes de las cosas sentidas, las cuales quedan allí a disposición del pensamiento que las recuerda". ${ }^{37}$ En concordancia con este presupuesto, la memoria el entendimiento y la voluntad eran los tres componentes del espíritu humano de acuerdo con la teología medieval heredada a la modernidad. Partiendo de esta idea, las religiosas "vieron" escenas procesadas con antelación. En ningún caso se trató de nuevas composiciones. Las descripciones aparecieron una a una, siguiendo, en términos generales las partes de la retórica agustiniana: Invetio, dispositio, elecutio, memoria y pronuntiatio. ${ }^{38}$

En este sentido, podemos afirmar que las visiones que se presentaban a las monjas en la soledad de sus celdas eran producto de una metodología basada en asociaciones mentales visuales, auditivas y experimentales. Ésta fue conocida por su fundadora y por ellas a partir de practicar los ejercicios espirituales de san Ignacio. En este caso, también cabe suponer que las monjas pudieron referirse a pinturas o estampas vistas en sus casas o en las iglesias de su natal España. ${ }^{39}$ Cada relato obedeció a codificaciones iconográficas que permitían su identificación, pues, todas estaban dentro de un espectro otorgado por la imaginería devocional tridentina. ${ }^{40}$ Seguramente la reliquia, en otro ámbito cultural y en otra temporalidad podía adquirir otras significaciones.

Ya en conjunto, el total de las 114 apariciones descritas se presentaron bajo 24 diferentes advocaciones repetidas y distribuidas en

${ }^{37}$ Báez Rubí, Mnemosine novohispánica, 400 y 401.

${ }^{38}$ San Agustín de Hipona, Confesiones: 40-401, Citado por Báez Rubí, Mnemosine novohispánica, 217 y 218.

${ }^{39}$ Los Ejercicios espirituales fueron publicados por primera vez en 1548 , ejercieron una influencia proverbial en la espiritualidad posterior como herramienta de discernimiento, aportando una metodología de interiorización individual.

${ }^{40}$ Se pueden citar varios ejemplos de manuales de pintura que recogen las recomendaciones conciliares, de algunos de éstos consta el haberse utilizado en la Nueva Espańa, se pueden consultar: Francisco de Holanda, De la pintura antigua (1548), trad. Manuel Denis (Madrid: 1921); Vicente Carducho, Diálogos de la pintura. Su defensa, origen esencia, definición, modos y diferencias [Madrid: 1633], ed., Francisco Calvo Serraller, (Madrid: 1979); y Francisco Pacheco, Arte de la pintura, su antigüedad y grandezas (1641) (Madrid: Librería de D. León Pablo Villaverde, 1871), 90. Este recurrido autor, a manera de ejemplo, menciona como debe representarse a san Jerónimo, "como él mismo Santo dice, y que no se le pinte viejo, porque cuando hizo penitencia en el desierto era de treinta ańos de edad". 
cinco grupos de imágenes. Las cristocéntricas representaron $50 \%$, correspondieron al santoral carmelitano un $20.1 \%$ y a las mariológicas correspondió $17.54 \%$, a los santorales de diversas Órdenes y las referentes al Nuevo Testamento sólo fueron $12 \%$. El cuadro 3 sirve de referencia para evaluar la importancia de la repetición de la escena aludida, la forma que cobra y la dinámica de las descripciones individuales a partir de su centralidad, desplazamientos y posiciones corpóreas.

Cuadro 3. Relación de apariciones descritas en la reliquia de santa Teresa, 1618

\begin{tabular}{|c|c|c|c|c|c|}
\hline 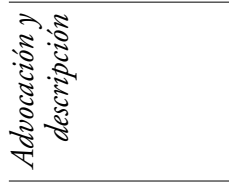 & 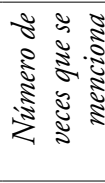 & 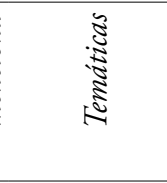 & 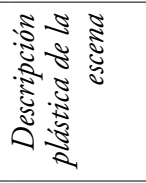 & 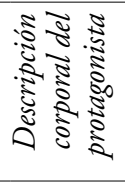 & 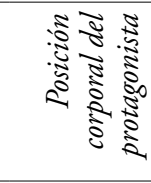 \\
\hline Monja Carmelita & 10 & $\begin{array}{l}\text { Santoral } \\
\text { Carmelitano }\end{array}$ & Completa & $\begin{array}{l}\text { Cuerpo } \\
\text { entero }\end{array}$ & Acostado \\
\hline Niño Jesús & 10 & Cristológica & Completa & $\begin{array}{l}\text { Cuerpo } \\
\text { entero }\end{array}$ & Acostado \\
\hline $\begin{array}{l}\text { Oración del } \\
\text { Huerto }\end{array}$ & 10 & Cristológica & $\begin{array}{l}\text { Fragmen- } \\
\text { tada }\end{array}$ & $\begin{array}{l}\text { Cuerpo } \\
\text { entero }\end{array}$ & De rodillas \\
\hline Padre Eterno & 4 & $\begin{array}{l}\text { Neotesta- } \\
\text { mentaria }\end{array}$ & Completa & $\begin{array}{l}\text { Medio } \\
\text { cuerpo }\end{array}$ & De pie \\
\hline $\begin{array}{l}\text { Rostro de Cristo } \\
\text { con mano en la } \\
\text { mejilla }\end{array}$ & 17 & Cristológica & $\begin{array}{l}\text { Fragmen- } \\
\text { tada }\end{array}$ & Cabeza & De lado \\
\hline $\begin{array}{l}\text { Rostro de varón } \\
\text { (Padre Eterno) }\end{array}$ & 1 & $\begin{array}{l}\text { Neotesta- } \\
\text { mentaria }\end{array}$ & Completa & Cabeza & Erguida \\
\hline $\begin{array}{l}\text { Rostro hermoso } \\
\text { de mujer }\end{array}$ & 2 & s/e & Completa & Cabeza & Erguida \\
\hline Sagrada Familia & 6 & Mariológica & Completa & $\begin{array}{l}\text { Cuerpo } \\
\text { entero }\end{array}$ & Sentada \\
\hline San Ángel & 4 & $\begin{array}{l}\text { Santoral } \\
\text { carmelitano }\end{array}$ & Completa & Cabeza & Erguida \\
\hline San Antonio & 2 & $\begin{array}{l}\text { Santoral } \\
\text { franciscano }\end{array}$ & Completa & $\begin{array}{l}\text { Cuerpo } \\
\text { entero }\end{array}$ & Erguido \\
\hline
\end{tabular}


Cuadro 3. Relación de apariciones descritas en la reliquia de santa Teresa, 1618 (continuación)

\begin{tabular}{|c|c|c|c|c|c|}
\hline 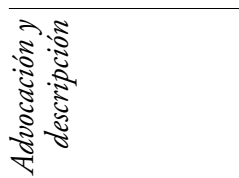 & 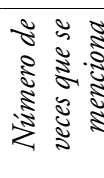 & 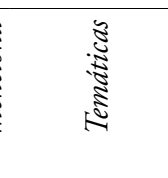 & 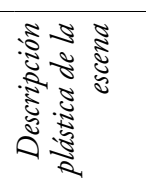 & 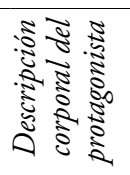 & 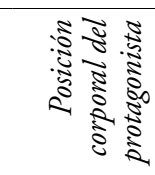 \\
\hline $\begin{array}{l}\text { San Francisco y } \\
\text { Cristo }\end{array}$ & 2 & $\begin{array}{l}\text { Santoral } \\
\text { franciscano }\end{array}$ & Completa & $\begin{array}{l}\text { Cuerpo } \\
\text { entero }\end{array}$ & Abrazado \\
\hline San Jerónimo & 1 & $\begin{array}{l}\text { Santoral } \\
\text { Jerónimo }\end{array}$ & Completa & $\begin{array}{l}\text { Cuerpo } \\
\text { entero }\end{array}$ & Sentado \\
\hline San Juan Bautista & 6 & Cristológica & Completa & $\begin{array}{l}\text { Cuerpo } \\
\text { entero }\end{array}$ & Erguido \\
\hline $\begin{array}{l}\text { San Juan de la } \\
\text { Cruz }\end{array}$ & 3 & $\begin{array}{l}\text { Santoral } \\
\text { carmelitano }\end{array}$ & Completa & $\begin{array}{l}\text { Cuerpo } \\
\text { entero }\end{array}$ & De rodillas \\
\hline San Pedro & 8 & Cristológica & $\begin{array}{l}\text { Fragmen- } \\
\text { tada }\end{array}$ & $\begin{array}{l}\text { Medio } \\
\text { cuerpo }\end{array}$ & Erguido \\
\hline $\begin{array}{l}\text { Santa Catalina de } \\
\text { Sena }\end{array}$ & 2 & $\begin{array}{l}\text { Santoral } \\
\text { Dominico }\end{array}$ & Completa & $\begin{array}{l}\text { Medio } \\
\text { cuerpo }\end{array}$ & Erguido \\
\hline $\begin{array}{l}\text { Santa Teresa de } \\
\text { Jesús }\end{array}$ & 6 & $\begin{array}{l}\text { Santoral } \\
\text { carmelitano }\end{array}$ & Completa & $\begin{array}{l}\text { Cuerpo } \\
\text { entero }\end{array}$ & De rodillas \\
\hline Santa Verónica & 5 & Cristológica & $\begin{array}{l}\text { Fragmen- } \\
\text { tada }\end{array}$ & $\begin{array}{l}\text { Cuerpo } \\
\text { entero }\end{array}$ & De pie \\
\hline $\begin{array}{l}\text { Santísima Trini- } \\
\text { dad }\end{array}$ & 1 & $\begin{array}{l}\text { Neotesta- } \\
\text { mentaria }\end{array}$ & $\begin{array}{l}\text { Fragmen- } \\
\text { tada }\end{array}$ & $\begin{array}{l}\text { Cuerpo } \\
\text { entero }\end{array}$ & Sentados \\
\hline Serafines & 1 & Mariológica & $\begin{array}{l}\text { Fragmen- } \\
\text { tada }\end{array}$ & Cabezas & Inclinados \\
\hline $\begin{array}{l}\text { Virgen con niño } \\
\text { Jesús }\end{array}$ & 3 & Mariológica & Completa & $\begin{array}{l}\text { Cuerpo } \\
\text { entero }\end{array}$ & Sentada \\
\hline $\begin{array}{l}\text { Virgen con Santa } \\
\text { Teresa }\end{array}$ & 1 & Mariológica & Completa & $\begin{array}{l}\text { Cuerpo } \\
\text { entero }\end{array}$ & Sentada \\
\hline $\begin{array}{l}\text { Virgen de la Con- } \\
\text { cepción }\end{array}$ & 8 & Mariológica & Completa & $\begin{array}{l}\text { Cuerpo } \\
\text { entero }\end{array}$ & Sentada \\
\hline Virgen del Pópolo & 1 & Mariológica & Completa & $\begin{array}{l}\text { Cuerpo } \\
\text { entero }\end{array}$ & Sentada \\
\hline
\end{tabular}

Fuente: Elaboración propia a partir de la transcripción paleográfica de la "Relación de lo que pasó en el convento de las Madres carmelitas descalzas de San José de la ciudad de los Ángeles”. ACSTP. 


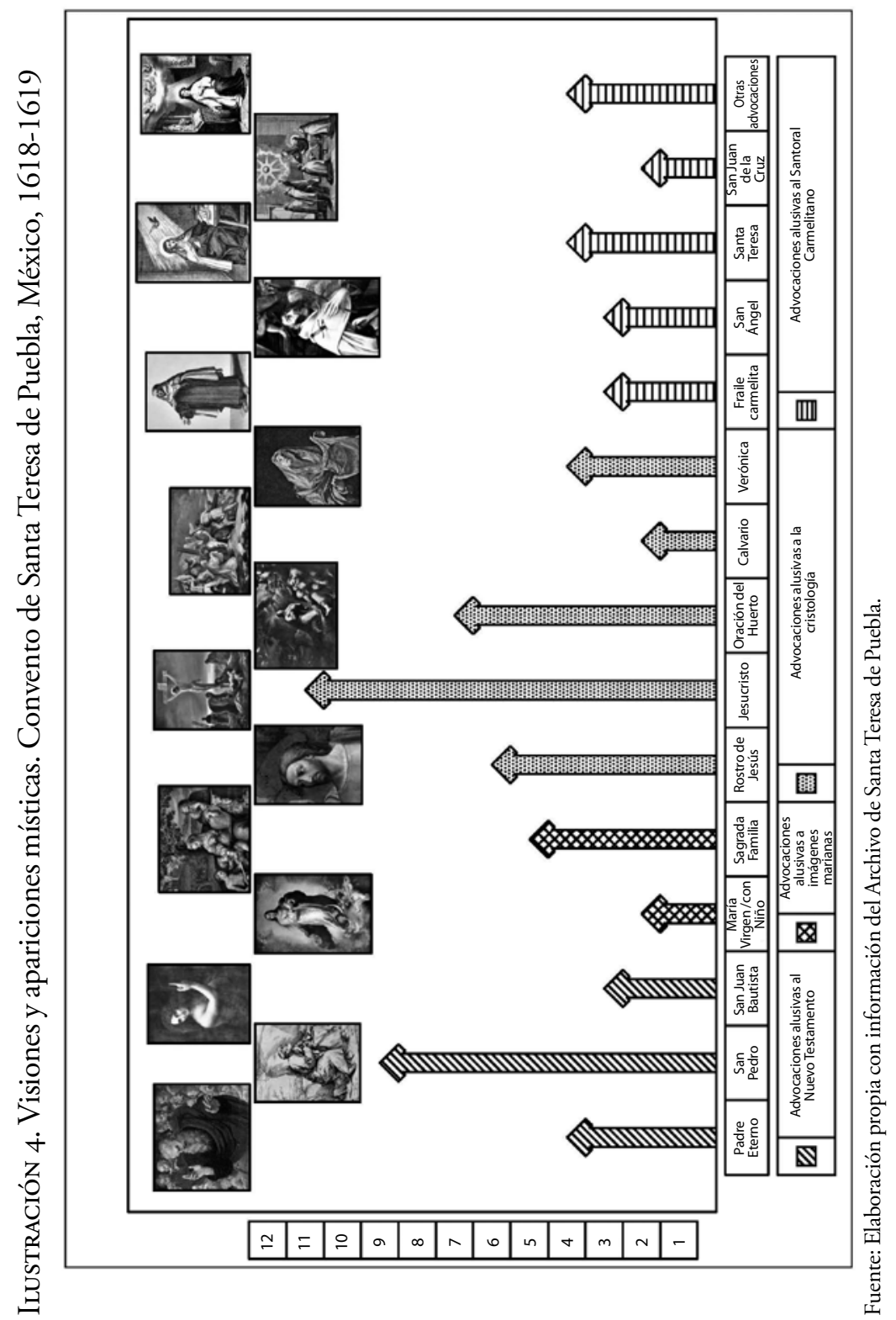



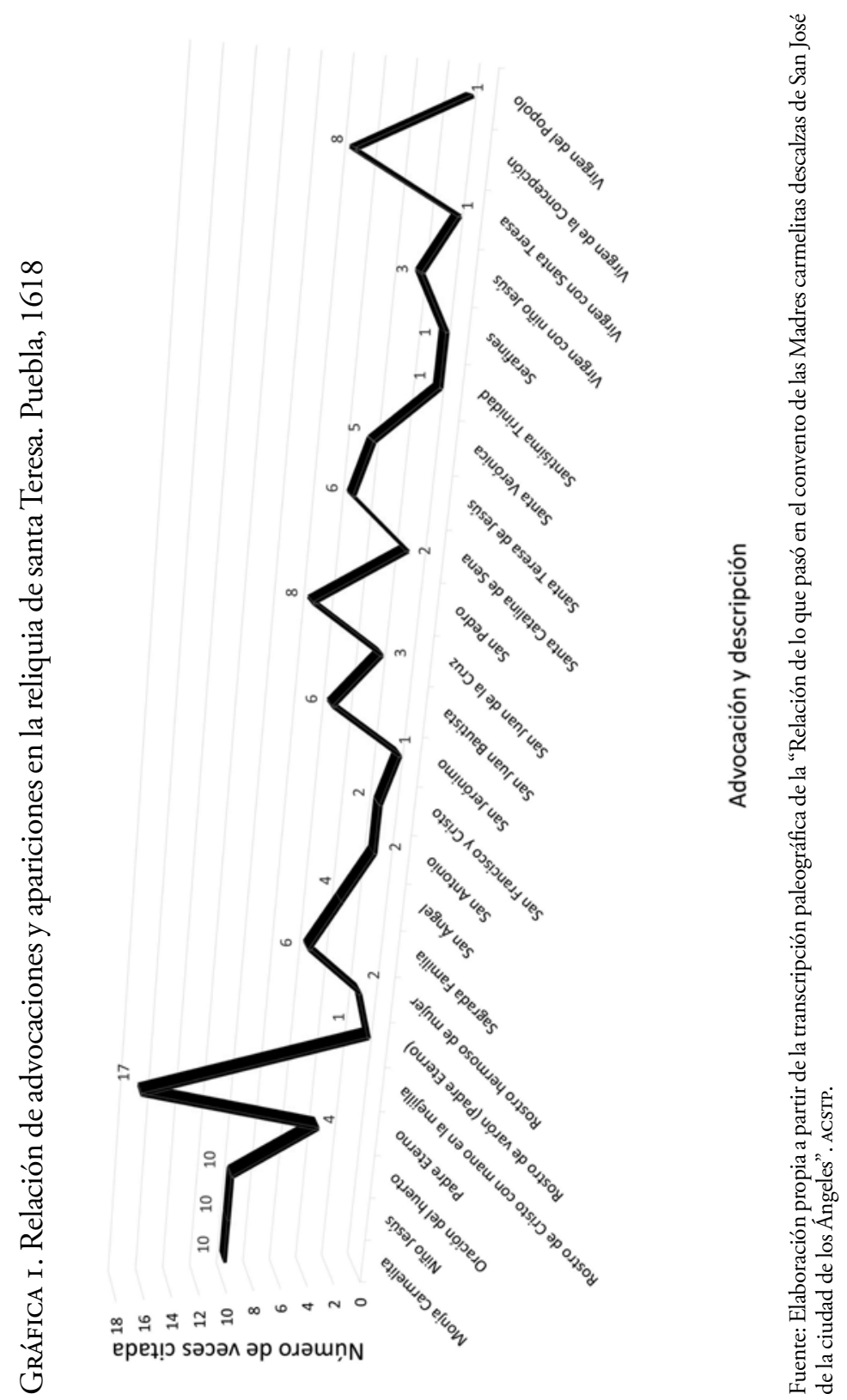


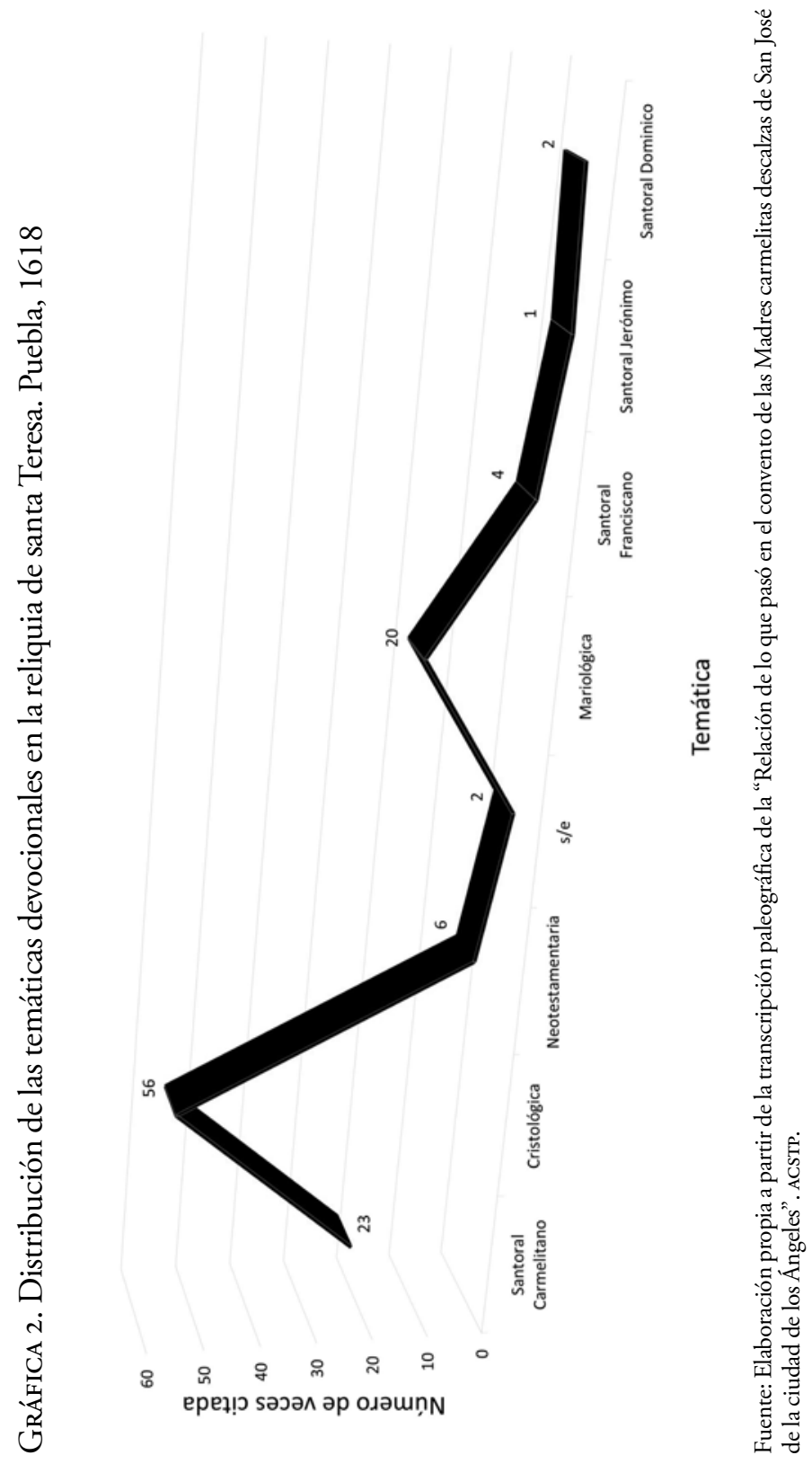


Las imágenes de la Pasión de Cristo estuvieron centradas en el rostro ensangrentado de Jesús, su presencia en el camino al Calvario acompañado de "una mujer que se entiende es la Verónica", en la Oración del Huerto, como Ecce Homo, Crucificado, o en el descendimiento donde aparece junto con su Madre, con María Magdalena y con santa Verónica. ${ }^{41}$ Éste fue el conjunto visionario más recurrente, pues, apareció mencionado por todas las religiosas involucradas.

La definición de las imágenes comprendidas en el santoral carmelitano fue hasta cierto punto ambigua, pues, debemos considerar que Teresa de Jesús recién había sido beatificada en 1614 y fue en 1622 cuando se canonizó, las referencias de las apariciones que aquí tratamos se ubican justo en medio de este proceso y por esta razón aparece la monja con hábito carmelitano, difunta, yaciente, pero para diferenciarla aparece con diadema de oro. En otra versión de la misma escena, la religiosa es acompañada de dos personajes, uno de ellos es la Virgen, quien aparece cuidándola a sus pies. Metafóricamente la imagen de la monja muerta y amortajada pudo asociarse con la felicidad brindada a partir del encuentro definitivo con su amado Esposo o también pudo representar el bien morir para las religiosas, pues, la mujer yaciente se describió recostada acompañada de la constante figura de una mujer con manto azul que le coloca la mano en el pecho, esta descripción iconográfica permite deducir que se trata de la virgen María. ${ }^{42}$ Parte de la imprecisión iconográfica de estas escenas pudo deberse a interpretaciones personales que las religiosas hicieron de los contenidos del libro "de la Santa" y a la poca difusión y circulación de grabados dedicados a su vida. ${ }^{43}$ Esta

${ }^{41}$ De manera particular la aparición de este personaje alude a la representación de la impregnación del rostro de Cristo en un manto convirtiéndolo instantáneamente en una reliquia, Verónica es la Vera icona... Gélis, "El cuerpo, la Iglesia y lo sagrado", 31.

${ }^{42}$ En la mayoría de las pinturas de las monjas difuntas se les representa con una corona y una palma de flores. La palma depositada en las manos significaba las privaciones y renuncias de la vida concebida como un largo martirio. La corona alude al tránsito gozoso a la gloria eterna reservada solamente para las almas justas (que han recibido la gracia).

${ }^{43}$ Se sabe que Hieronimus Wierix (Amberes 1553-1619) realizó una de las primeras series de la vida de la Santa, pero quizás por lo contemporáneo de su factura, en el momento del suceso de la reliquia aún no se conocía en Nueva España. Sobre la presencia de grabados en el Nuevo Mundo, debemos subrayar la importancia de la escuela flamenca. 
ambigüedad también se repite con fray Juan de la Cruz, dado que fue beatificado en 1675 y canonizado hasta 1726, por eso sus alusiones requirieron de la validación expresada a través de su reconocimiento en las estampas que llegaban de España.

Las representaciones mariológicas cobraron una importancia particular si consideramos que recién en 1616, antes que en Toledo, los cabildantes del Cabildo Catedral junto con los del Ayuntamiento de la ciudad de Puebla se habían declarado como defensores del dogma de Fe Inmaculista. A partir de esa fecha las dedicaciones de las iglesias poblanas corresponderían a esta intención. Se representó a la Virgen apocalíptica, con el niño en brazos, en el pesebre y junto con san José conformando la Sagrada Familia.

Complementariamente se mencionó, de manera proporcional un grupo de representaciones alusivas al Nuevo Testamento: san Pedro y san Jacobo y san Juan Bautista. En esta lista, tuvo lugar especial la presencia del Padre Eterno como principio de autoridad y de convalidación a las recomendaciones tridentinas. ${ }^{44}$ En menor proporción se mencionaron otras advocaciones dominicas y franciscanas.

Cada visón permitió interpretar determinados aspectos de la organización del mundo para cada religiosa. Ya fuera con escenas completas, fragmentadas o con la aparición de simples signos icónicos, las monjas apuntaban o describían objetos precisos, singulares y concretos, expresaban lo que ellas "veían" o lo que sabían del tema, por ejemplo, el cordero con diadema aludía a san Juan Bautista mientras que la mujer con el manto en las manos y que mostraba el rostro de Cristo se asoció con santa Verónica, san Ángel siempre fue fácil de identificar debido a la presencia de un hacha en medio de su

$\mathrm{Al}$ respecto pueden verse Estampa europea de los siglos XV y XVI, Colección Manuel Álvarez Bravo (México: Museo Sumaya, 1998); Vicenc Furió, El arte del granado antiguo. Obras de la colección Furió (Barcelona: Universidad de Barcelona, 2000) y el trabajo de Ilja M. Veldman, Images for the Eye and Soul: Function and Meaning in Netherlandish Prints (1450-1650) (Leiden: Primavera Pers, 2006).

${ }^{44}$ De manera particular la presencia del Padre Eterno fue compleja, pues, en el Nuevo Testamento su reconocimiento es aplicado a la figura de Jesús, con este atributo se convierte en característica propia de la relación particular de la Nueva Israel y Dios. Gerhard Bellinger et al., Diccionario ilustrado de la Biblia (León: Editorial Everest, 1985), 482. Como figura iconográfica aparece también formando parte de la Santísima Trinidad. 
cabeza. En estos casos, el signo icónico apuntaba a contenidos simbólicos narrativos o retóricos cuando se trató de aludir a lo inasible a lo irrepresentable como la Gloria. ${ }^{45}$

Las proporciones se armonizaban en relación con la perspectiva, las imágenes descritas por las monjas cobraban una tercera dimensión: los rostros se describieron de frente, los cuerpos enteros, o "desde la garganta para arriba". En la visón de Micaela de Santiago. La posición de los personajes cobra importancia para jerarquizar su lugar en la escena, pues, después de la Virgen con el niño, "más allá, estaba san José” de esta manera, el padre de Jesús aparece "más pequeño". Los desplazamientos de los personajes también estuvieron regulados equilibradamente además de ser realistas. En estas representaciones de varios planos simultáneos, como se muestran en los grabados de la época, la razón áurea proporcionaba a cada personaje en la escena una particular importancia. ${ }^{46}$ Veamos con detenimiento las variaciones en estas imágenes.

Las escenas se presentaron bajo dos formas: completas o enfatizando tan sólo una sección o algún elemento que simbólicamente hacía referencia a la escena completa, a un fragmento o al personaje. En las escenas integradas se distribuyó la información visual y de contenidos a partir de la perspectiva horizontal. Por ejemplo, en la Oración del Huerto es factible definir la importancia de los protagonistas a partir del orden como se van describiendo. En un primer plano los apóstoles descansando, en una segunda línea y otorgando centralidad a la escena aparecía Jesús orando y a un lado en una mínima proporción, los soldados aluden a la próxima aprehensión del protagonista al portar las lanzas, que se convierten en elementos iconográficos de las escenas pasionales. Los elementos topológicos de la narración regulan la disposición de las figuras en el espacio gracias a la memoria. En la misma escena, el hecho de que se describa al Nazareno de perfil, sin frontalidad, rezando con las manos juntas o hincado, remite al lector la idea de la humildad como componente de la oración mental. En este caso, las figuras conformaban

${ }^{45}$ Víctor I. Stoichita, El ojo místico, 77, 83 y 159.

${ }^{46}$ Władysław Tatarkiewicz, Historia de la estética III. La estética moderna 1400-1700 (Madrid: Akal, 1991), 71. 
parte de un paisaje iconográfico coherente a través de relaciones asociativas como los árboles, el monte o el ángel o la noche. ${ }^{47}$ Esta escena fue recurrente en los casos de Elvira de San José, Francisca de la Natividad, Micaela del Sacramento, Catalina de San José y la propia Melchora de la Asunción, quien aporta la relación más completa de esta representación:

Vio a Cristo Nuestro Señor de la suerte que le pintan cuando estaba en el huerto postrado y en tanta manera se mostraba maltratado y ensangrentado y afligido de la agonía y sudor de sangre [se mezcla en este segmento de la descripción la escena de la coronación de espinas]. Delante del Señor estaban y están tres personas quien en el modo de la postura y en todo, uno portaba una insignia como de arma, que tiene el uno, sin duda son los tres apóstoles que estaban en el huerto con Cristo nuestro Señor. El del arma se entiende era san Pedro, es más anciano, el otro no lo es y el otro es muy mozo. Están [...] actualmente como los pintan durmiendo en el huerto, otras [monjas] ven aquí también al ángel que está confortando a nuestro Señor. ${ }^{48}$

Con la información descrita se dotaba de coherencia a un texto visual imaginado. En los temas de escenas de la Pasión, se trató de paisajes abiertos y en perspectiva horizontal; como en el caso anteriormente descrito o vertical como en el Descendimiento, en estas imágenes el simbolismo se concentraba a partir de la cruz que se convertía en el punto de fuga hacia el firmamento. A su vez este instrumento de tortura cobraba un protagonismo per se en el desarrollo de otras imágenes, podía citarse como objeto alusivo a algún

47 "Para representar la muerte humana con un emblema representaron la noche obscura con este mote VERTETUM IN DIEM (se convertirá en día). Por la promesa Divina creemos firmemente en la resurrección después de la muerte. [...] con el mismo emblema se alude a las calamidades soportadas con ánimo sereno, abren el camino a la luz clarísima de la felicidad venidera”. Filippo Picinelli, Los cuerpos celestes, Libro I (El mundo simbólico), índices y edición de textos latinos e italianos de Bárbara Skinfill Nogal, 341 (Zamora: El Colegio de Michoacán, 1997).

${ }^{48}$ La descripción más amplia corresponde a la priora quien dijo que: "Tomando otra vez la reliquia, estando en la recreación empezó la sangre a hervir y a la dicha madre priora a acelerársele el corazón, aunque lo disimulaba". ACsTP, "Relación de lo que pasó", f. 4. 
Imagen de la Oración del Huerto

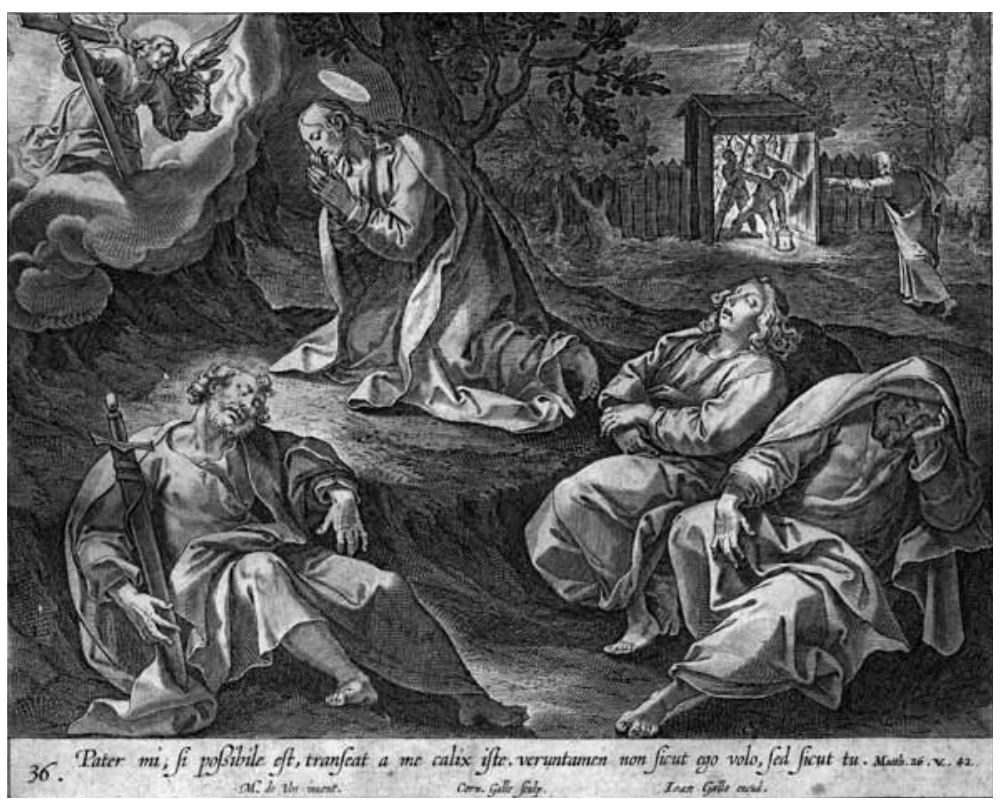

Oración del Huerto. Calcografía a buril, 19.4 x 27.1; Inventor Martín de Vos, Cornelio Galle, Sculptor y Joan Galle Execud. C. 1590, Escuela flamenca, Colección particular.

santo en su celda o inspiraba imágenes mucho más complejas como en el Calvario o en la visión de san Francisco cuando se le describe siendo coparticipe del escurrimiento de la sangre de Jesús. ${ }^{49}$

En las apariciones, la utilización de recursos de composición plástica como la perspectiva, la fragmentación en planos y la jerarquización de símbolos se complementó con textos que permitían precisar aún más los elementos de cada escena y sus significaciones. Así se justificaba el remitirse a colores, texturas y formas, las cosas y

49 "La madre Juana de San Pablo vio un Cristo crucificado con la cabeza inclinada y muy descoyuntado [...] un brazo porque estaba de soslayo [...] y ve un religioso con capa y capilla blanca abrazado con este Santo Cristo y la cabeza inclinada de modo que cae debajo de la de Cristo, que también lo está (el rostro del religioso con su cerquillo es más redondo que aguileńo), el religioso que estaba abrazando a Cristo participa de la sangre del mismo Señor, de suerte que le cae sobre la garganta y el pecho". ACSTP, "Relación de lo que pasó en el convento", f. 3. 
su nominación se asociaron con un realismo natural. ${ }^{50}$ Describir y escribir las experiencias de estas religiosas permitió el diseño de un texto visual basado en narraciones o en hechos extraordinarios. Se trató de un proceso interactivo donde la mirada "imaginaria" de la observadora se inscribía en una retórica mística que aludía a lo terreno pero también a lo sagrado. Se desarrolló una metodología de la descripción plástica seguida por todas con el objeto de transmitir mensajes significativos al observar la reliquia. Este texto colectivo se conformó gracias a la suma de las descripciones de sus participantes. Éstas sintetizaban y recomponían los temas, no obstante, cada imagen fue reconocida por las otras religiosas gracias a su asociación temática, tipológica e iconográfica. Este ejercicio permitía compartir una visión momentánea del mundo, lo hacía legible y, por lo tanto, manipulable.

\section{LA IMAGEN COMO TEXTO. LA ESTÉTICA DEL BARROCO}

Si bien, el arte del barroco en la primera mitad del siglo XvII estuvo determinado por los cánones eclesiásticos y políticos, también es cierto que su implantación en el Nuevo Mundo compartió hitos de una modernidad plástica que estaba emergiendo en la Europa católica. ${ }^{51}$ Puede considerarse que el tomismo fue la base del racionalismo estético de la modernidad renacentista. En su obra magna, la Suma Teológica (1265-1273), Tomas de Aquino explica la relación entre el sujeto y el objeto a través de la percepción. El objeto se manifestaba como forma, y el sujeto se percibía gracias a la sensibilidad. Entre las dos se generaba por primera vez una afinidad estructural: lo bueno era bello, blanco, armonioso. Mientras que lo malo era obscuro, tenebroso y bajo. ${ }^{52}$ Surgían así asociaciones estéticas y mo-

\footnotetext{
${ }^{50}$ Representar significa evocar por descripción, retrato o imaginación. Situar semejanzas de algo ante la mente o los sentidos, estar en lugar de otra cosa a través de una representación, de ofrecer de nuevo pero transformado en signo. Representación es sustitución, es una operación mental. Michel Foucault, Las palabras y las cosas, $18^{\mathrm{a}}$ edición (México: Siglo XXI, 1988), 53-83.

${ }^{51}$ Umberto Eco, Historia de la belleza (Barcelona: Lumen, 2004), 176-178.

52 Sin olvidar la ambivalencia iconológica tan recurrente en los textos místicos. La noche obscura precede en momentos de unión mística.
} 
rales. Se distinguían en la belleza tres cualidades: la integridad de la escena que aludía a la idea completa del tema representado, la armonía, es decir, la correcta proporción de las partes de un objeto; y la claridad, que relacionaba la belleza con la luz como símbolo de verdad, siguiendo la tradición neoplatónica. ${ }^{53}$ En las descripciones de las monjas carmelitas, la luz, los destellos, los relámpagos aparecieron asociados a la Virgen y objetos portados por ella como se muestra en el párrafo de Isabel de la Encarnación que vio "un collar muy lindo y una o dos piezas de él daban más resplandor que algunas estrellas que entre las demás relucen más están relampagueando" ${ }^{54} \mathrm{De}$ manera particular, ésta es la única escena descrita en torno a un objeto precioso, se puede sugerir que la misma luz que ella ve la envuelve, otorgándole una gracia especial, pues, de todas las visionarias carmelitas sólo ésta fue biografiada con intenciones de apoyar la introducción de su causa en el Vaticano. ${ }^{55}$

En continuidad con esta propuesta, uno de los elementos más importantes de los textos, además de las advocaciones relatadas e identificadas iconográficamente, se centraba en las cualidades aludidas en cada aparición. Su asociación con escenas conocidas formó parte de un sistema devocional específico. Por ejemplo, en las relativas al Padre Eterno, las nubes desempeñan el rol de enmarcamientos, encuadres luminosos o rompimientos portentosos. ${ }^{56}$ Las exaltaciones simbólicas, definidas por tratadistas y descritas por las religiosas como "las nubes arreboladas", fueron epítetos asociados a una lectu-

${ }^{53}$ Curtis Beardsley Monroe y John Hospers, Estética. Historia y fundamentos (Madrid: Cátedra, 1990), 39-40.

${ }^{54}$ Isabel de la Encarnación, ACSTP, "Relación de lo que pasó en el convento", f. 7.

${ }^{55} \mathrm{Al}$ respecto puede verse Báez Macías, Fray Agustín de la Madre de Dios y Pedro Salmerón, Vida de la venerable madre Isabel de la Encarnación (Pamplona: Universidad de Navarra, Iberoamericana-Vervuert, Bonilla Artigas Editores, 2013).

${ }^{56}$ En la Biblia las nubes son instrumentos de revelación. Muestran y ocultan a la vez asumiendo así su estatus límite entre lo visible y lo inasible. La dialéctica nube/gloria, tal y como aparece en el Éxodo será fundamental para toda la experiencia teofánica judeocristiana. Si bien, la gloria ciega por su resplandor, paradójicamente la nube la hace visible al ocultarla. En la mística española la relación nube/gloria es inestable. Para san Juan de la Cruz es tan sólo una inútil barrera entre lo místico y lo divino. Víctor I. Stoichita, El ojo mistico, 81 . 
ra iconológica que aludía a las más importantes manifestaciones de la divinidad. Cuando se refirieron a la presencia de la Santísima Trinidad mencionaban sin lugar a dudas una hierofanía, esto es, una de las máximas experiencias de la mística, perceptible únicamente para religiosas escogidas. ${ }^{57}$ En las narraciones resultaba sumamente difícil explicarla dado su alto grado de abstracción, no basta considerar la presencia de las tres figuras conocidas, sino que hacía falta expresar su importancia a través de su dinámica visionaria. Melchora de la Asunción vio en el Misterio de la Santísima Trinidad:

a su parecer le parecía que era el Padre Eterno el que estaba arriba en una nube, aunque no se veía con distinción [...] luego más abajo una palomita, luego un rostro de Cristo Nuestro Señor con corona de espinas. Después de haberlo visto muy bien desaparecía la palomita y el rosto del Señor y después, sin quitarse la reliquia de la mano vio en el mismo lugar un rostro del Señor muy lindo, aguileño, de barba partida y muy risueño y alegre, después vino la palomita y el rostro del Señor se tornó afligido. ${ }^{58}$

Cada figura descrita adquiría valor en función de la coherencia entre su contexto y la narración, de este modo, todas las religiosas sabían a qué imagen se refería su compañera, se validaba la descripción en relación con la coincidencia en la interpretación de los códigos. ${ }^{59}$ En este sentido, su adjetivación cromática fue también un

57 "En la Sagrada Escritura está como se ha de pintar a Su Majestad, así debe representarse la Santísima Trinidad, al Padre eterno en figura de un grave y hermoso anciano, con cabello largo y venerable barba, y ambas blanquísimas, sentado con gran majestad, como se apareció al profeta Daniel, con alba y manto de brocado, o túnica azul claro y manto morado carminoso; a su mano derecha sentado Cristo nuestro Seńor, como lo dice David y lo afirma la Santa Iglesia en el Credo, de 33 años de edad, con hermosísimo rostro y bellísimo desnudo, rubio y de ojos azules, con las llagas en manos, pies y costado, con manto rojo y arrimado a la Cruz: en medio de ambos y más alto el Espíritu Santo en forma de paloma; acompáńese este misterio con resplandores, Ángeles y Serafines, que asisten con admiración y respeto". Francisco Pacheco, Arte de la pintura, 84.

${ }^{58}$ ACSTP, "Relación de lo que pasó en el convento", f. 4

${ }^{59}$ Umberto Eco, Tratado de semiótica general (Barcelona: Lumen, 2000), 81-156. En el caso de las narraciones aquí descritas, en ocasiones aparecen las escenas entremezcladas, pero básicamente se repiten los elementos iconográficos más representativos de acuerdo con los códigos de representación aprendidos. 
instrumento de composición, clasificación, e identificación: “de barba muy blanca" "piel blanca como el marfil", "cabello rubio como el oro". ${ }^{60}$ Se recurrió a estos calificativos a partir de al menos un elemento de identidad. Por ejemplo: mediante la utilización de la palabra blanco se definió la ancianidad y benevolencia de san Pedro, su presencia podía interpretarse como sustituto de Cristo en la tierra y por lo tanto de dador de salvación. ${ }^{61}$

A la virgen María como intercesora de los pecadores ante su divino hijo, se le describe majestuosa, vestida de azul y coronada. ${ }^{62} \mathrm{Su}$ representación es el resultado de una nueva iconografía producto de la visión de san Juan en Patmos descrita en el capítulo XII del Apocalipsis y de la interpretación tridentina de Dios como creador de la madre de Cristo, sin mancha alguna. Así aparece una mujer vestida de Sol parada sobre una luna sostenida por querubines. ${ }^{63}$ En las descripciones la sola presencia de estos seres, junto con la de la luz del sol y de la luna, evocaban iconográficamente la presencia de

${ }^{60}$ Para los tratadistas de pintura de los siglos xvı y Xviı, la pintura es la suma de la luz y la oscuridad y un juego de claroscuro, lo que aporta el movimiento a las imágenes. Según Leonardo, la tiniebla es el cuerpo y la luz el espíritu, siendo la mezcla de ambos la vida. Tatarkiewicz, Historia de la estética III, 71.

${ }^{61}$ ACSTP, "Relación de lo que paso en el convento". Esta imagen es coincidente para Elvira de San José, Francisca de la Natividad, Juana de San Pablo y Micaela de Santiago, quienes asocian a san Pedro con un lucero resplandeciente, más adelante, Catalina de San José y Ana de la Concepción coincidieron en esa percepción sobre el santo.

62 "La Concepción, se ha de pintar en la flor de la edad de esta Santísima Señora, de doce a trece años, hermosísima, de lindos y graves ojos, nariz y boca perfectísima, y rosadas mejillas, los bellos cabellos tendidos, de color de oro; con túnica blanca y manto azul, que así apareció á D. Beatriz de Silva, Portuguesa, que fundó la religión de la Purísima Concepción, que confirmó el Papa Julio II ańo de 1541: coronada de doce estrellas, compartidas en un círculo claro entre resplandores; debajo de los pies la media luna con las puntas hacia abajo, porque estando sobre el convexo para que la alumbre, adornase con ángeles y serafines enteros, que tienen algunos de los atributos: algunos ponen el dragón hollada su cabeza por el santísimo pie de la Virgen”. Francisco Pacheco, Arte de la pintura, 87.

63 "Los Querubines del Arca, eran también niños, y con rostros de niños se deben pintar. Se les pinta con alas hermosísimas de varios colores imitadas del natural [...] porque dan a entender su levantado ser, la agilidad y presteza de que están dotados, como bajan del cielo libres de toda pesadumbre corpórea, y tienen siempre fijas sus mentes en Dios; entre nubes, porque el cielo es su propia morada, y para que nos comuniquen templadamente la inaccesible luz de que gozan”. Francisco Pacheco, Arte de la pintura, 85. 
María. ${ }^{64}$ De manera paralela que en España, su advocación dio inicio con visiones y su representación comenzó a ser plasmada hasta convertirse en una imagen devocional exitosa en ambos continentes, sus atributos iluminadores remiten a la posibilidad de recibir el amor y gratitud debido a los rayos de gracia y beneficencia divina que le acompañan como luz que resplandece de día. ${ }^{65}$

De manera complementaria otras características físicas definieron la autenticidad e importancia de la reliquia, ésta, al igual que otras ya santificadas, también sangraba, como si estuviese recién cortada, parecía y se comportaba como un fragmento de un cuerpo vivo. La escritora pone como un antecedente que el fragmento de piel tenía una "partidura desde que la trujeron de España” y al observarla, la madre Francisca de la Natividad, después de identificar el rostro de Jesús "muy afligido con la mano en la mejilla" vio que por la mencionada grieta:

La carne se fue cubriendo con el nacimiento de grande hervor de la sangre que patentemente se veía hervir la sangre y de la fuerza con que la juntura soldó parece que exprimía sangre el rostro. Estaba tan alterado que los labios se le abrieron y se le aparecía lo blanco de los dientes con la hinchazón de los labios, dijo, se le abrió la boca. De una ventana de la nariz derecha apuntaba a salir sangre muy patente y fresca, como si en aquel punto la sacaran de un cuerpo vivo y todo el rostro cárdeno y que parecía quería reventar todo en sangre [...] de tal manera se representó una imagen tan dolorosa y significativa de lo que pasó en su pasión que no se puede decir con palabra. ${ }^{6}$

Como resultado de esta visión a la madre priora se le aceleró tanto su pena que perdió la vista de los ojos. Esta descripción de la herida

${ }^{64}$ No debe pasarse por alto que estas composiciones iconográficas son de nuevo cuño en la historia del catolicismo y que su presencia debía ratificar su asociación con el Nuevo Testamento ya que en el Génesis (Gn 1, 16; cfr. Sal 136, 9) la luna, por ejemplo, fue un lucero creado por Dios "para el dominio de la noche" y el culto a la luna al igual que los demás dioses celestes quedó prohibido a los israelitas. Por otro lado, también su presencia se asoció con la fertilidad. Gerhard Bellinger, Diccionario ilustrado de la Biblia, 386.

${ }^{65}$ Filippo Picinelli, Los cuerpos celestes, 131.

${ }^{66}$ ACSTP, "Relación de lo que pasó en el convento", f. 2. 
sangrante puede asimilarse con la iconografía de la heráldica de la piedad. Ésta se constituyó a partir del esquema generado por las llagas de Cristo y la herida del costado. De manera particular sobre la incisión aparecieron escenas como la de san Francisco estigmatizado.

El rostro sangrante aludía a la nobleza de la humanidad cifrada en la cabeza y el pecho del hijo de Dios humanizado. Además del procedimiento de identificación de la imagen de Cristo, en su mutación se recurría a una asociación directa entre la sangre y el dolor, propiedades específicas atribuibles a la santidad cristiana. Al menos tres elementos entraban en juego para la comprensión y composición de esta imagen pasionaria. La conjunción de las imágenes acústicas generadas por la lectura en voz alta en refectorios y sermones propios de la temporada de cuaresma. Las visuales, plasmadas en lienzos y grabados que circulaban para su uso didáctico. Y las cenestésicas recreadas en las procesiones, particularmente la de semana Santa, que pasaba frente al convento precedida de un Cristo en andas procedente de la parroquia de San José en su camino hacia la catedral. ${ }^{67}$

En el universo barroco se permitía la dramatización extrema, pero la validación de la imagen dependía de las repeticiones temáticas y de las coincidencias interpretativas, 11 de las 14 mujeres enclaustradas vieron esta misma escena de la Pasión. Cabe reflexionar que estos modelos de religiosidad recién se estaban difundiendo y creando tradición en América y que de esos cuerpos muertos, que también estaban vivos, se esperaban maravillas.

\section{TEXTOS, EXPRESIONES Y REGÍMENES EMOCIONALES DEL BARROCO}

Partimos de la idea de que la historia de las emociones permite problematizar sentimientos del pasado a partir de conocer sus diversas manifestaciones textuales. El objetivo de este apartado es reflexionar brevemente en torno a los testimonios descritos por las religiosas en

${ }^{67}$ Michel Arrivé e Izabel Vilela, "Lenguaje e inconsciente en Freud: representaciones de las palabras y representaciones de las cosas", en "Semiótica y psicoanálisis", Tópicos del Seminario (44) (2004): 51-76. 
1618 , con el fin de definir algunos de los rasgos de la cultura emocional del catolicismo occidental que ellas heredaron. ${ }^{68} \mathrm{La}$ utilización de símbolos e iconografía expresados en descripciones plásticas, representaron organizada y jerarquizadamente algunas de las conductas afectivas de las monjas mostrando que formaban parte de un sistema cultural que expresaba el poder y el control moral detentado por la Iglesia. ${ }^{69}$

Las imágenes descritas por las religiosas permiten inferir la gestualidad facial y corporal de sus personajes y su función en la transmisión de contenidos sentimentales significativos. Su estudio nos remite en un primer momento a la discusión teórica centrada en el estudio de las expresiones faciales como forma de reconocimiento universal de las emociones básicas (felicidad/tristeza, sorpresa, ira, miedo).$^{70} \mathrm{~A}$ partir de esta postura podemos proponer que, si bien, las manifestaciones emocionales tienen componentes biológicos y sociales, también es cierto que la mayoría de las expresiones faciales requieren claves contextuales para hacerse legibles. De esta manera, las emociones se expresan e interpretan según la sociedad en la que se incrustan y poseerán significados culturalmente específicos y sujetos a transformaciones o adecuaciones a través del tiempo. ${ }^{71} \mathrm{El} \mathrm{si-}$ guiente cuadro nos remite a algunos ejemplos de las coincidencias entre gestualidad, manifestación emotiva o cualidad asociada.

${ }^{68}$ Una definición de emoción tiene que ver con una disposición conductual generada automáticamente cuando el sistema cognitivo tiende a evaluar un evento de forma consciente o inconsciente con el objeto de detectar las propiedades del mismo (facilitadoras, obstaculizadoras, modificadoras positivas o negativas). Cada emoción de asocia con características fisiológicas diferenciables. Las funciones propias de estado mental son detonar una conducta, producir una respuesta y comunicarla hacia el exterior. David Casacuberta, Qué es una emoción (Barcelona: Crítica, 2000), 160.

${ }^{69} \mathrm{La}$ idea del constructivismo propone que "las emociones son una construcción social que consisten en ideas reguladoras para la sociedad". Esta interpretación resulta funcional para entender históricamente las jerarquizaciones de las pasiones y de las emociones durante los siglos XVI-XvIII. Sobre esta polémica véase Casacuberta, Qué es una emoción, 77.

${ }^{70}$ Esta tipología obedece a la denominada "teoría construccionista social de las emociones".

${ }^{71}$ Barbara H. Ronsenwein, "Problems and Methods in the History of Emotions, Journal of the History and Philosophy of the Emotions 1(1) (2010): 2-32; "Worrying about Emotions in History”, American Historical Review 107(3) (2002): 821-845. 
Cuadro 4. Advocaciones, gestualidad y representación afectiva

\begin{tabular}{|c|c|c|}
\hline Nombre de la monja & Advocación & $\begin{array}{l}\text { Sentimiento o afecto } \\
\text { o cualidad asociada }\end{array}$ \\
\hline \multirow[t]{2}{*}{ Elvira de San José } & Calvario & $\begin{array}{l}\text { Sin Cristo pero la cruz } \\
\text { está manando sangre }\end{array}$ \\
\hline & San Ángel & $\begin{array}{l}\text { Muerto como mártir con } \\
\text { hacha en la cabeza }\end{array}$ \\
\hline \multirow[t]{2}{*}{$\begin{array}{l}\text { Francisca de la } \\
\text { Natividad (priora) }\end{array}$} & Niño Jesús & $\begin{array}{l}\text { Muy blanco, rosado } \\
\text { y desnudito }\end{array}$ \\
\hline & Señor del Perdón & $\begin{array}{l}\text { Sangrando la cabeza } \\
\text { y afligido }\end{array}$ \\
\hline \multirow[t]{5}{*}{ Juana de San Pablo } & $\begin{array}{l}\text { Rostro de Cristo con } \\
\text { mano en la mejilla }\end{array}$ & $\begin{array}{l}\text { Afligido, la carne se } \\
\text { hincha y sangra }\end{array}$ \\
\hline & Santa Verónica & $\begin{array}{l}\text { Portando un rostro ator- } \\
\text { mentado }\end{array}$ \\
\hline & $\begin{array}{l}\text { San Francisco abrazado } \\
\text { a un Santo Cristo }\end{array}$ & Fraile bañado en sangre \\
\hline & Padre Eterno & $\begin{array}{l}\text { Lindo y grave con barba } \\
\text { como lo suelen pintar }\end{array}$ \\
\hline & Ecce Homo & $\begin{array}{l}\text { Cuerpo completo ensan- } \\
\text { grentado y sufriente }\end{array}$ \\
\hline \multirow[t]{2}{*}{ Micaela de Santiago } & Niño Jesús & $\begin{array}{l}\text { Túnica ceniza y cabello } \\
\text { de color de oro }\end{array}$ \\
\hline & $\begin{array}{l}\text { Fraile con Cristo en la } \\
\text { mano }\end{array}$ & $\begin{array}{l}\text { Expresión de unión } \\
\text { mística }\end{array}$ \\
\hline \multirow[t]{2}{*}{ Marina de la Cruz } & $\begin{array}{l}\text { Rostro de Cristo con } \\
\text { mano en la mejilla }\end{array}$ & $\begin{array}{l}\text { Afligido, fragmentado } \\
\text { y sangrante }\end{array}$ \\
\hline & $\begin{array}{l}\text { San Francisco abrazado } \\
\text { a un Santo Cristo }\end{array}$ & Expresión unión mística \\
\hline \multirow[t]{3}{*}{ Isabel de la Encarnación } & Padre Eterno & $\begin{array}{l}\text { Iluminado, barba larga } \\
\text { y cana }\end{array}$ \\
\hline & $\begin{array}{l}\text { Rostro de Cristo con } \\
\text { mano en la mejilla }\end{array}$ & $\begin{array}{l}\text { Afligido, sangre fresca } \\
\text { recién derramada }\end{array}$ \\
\hline & Collar & Relampaguea \\
\hline Mariana del Sacramento & $\begin{array}{l}\text { Rostro de Cristo con } \\
\text { mano en la mejilla }\end{array}$ & $\begin{array}{l}\text { Afligido, desnudo } \\
\text { y sangrante }\end{array}$ \\
\hline
\end{tabular}


Cundro 4. Advocaciones, gestualidad y representación afectiva (continuación)

\begin{tabular}{|c|c|c|}
\hline Nombre de la monja & Advocación & $\begin{array}{l}\text { Sentimiento o afecto } \\
\text { o cualidad asociada }\end{array}$ \\
\hline & Sagrada Familia & $\begin{array}{l}\text { San José como viejo } \\
\text { encanecido tomando la } \\
\text { mano del niño }\end{array}$ \\
\hline Catalina de San José & San Pedro & Estrella resplandeciente \\
\hline Josefa de José María & Rostro de Cristo & Afligido y sangrante \\
\hline Teresa de Jesús & San Pedro & Como un lucero brillante \\
\hline \multirow[t]{9}{*}{$\begin{array}{l}\text { Magdalena de San } \\
\text { Pedro }\end{array}$} & Padre Eterno & $\begin{array}{l}\text { En medio de una nube } \\
\text { arrebolada }\end{array}$ \\
\hline & Rostro de Cristo & $\begin{array}{l}\text { Afligido, con hilo de } \\
\text { sangre en la boca y tres } \\
\text { gotas sobre la frente }\end{array}$ \\
\hline & Virgen con niño & $\begin{array}{l}\text { Resplandores, crecidito } \\
\text { como cuando le pintan } \\
\text { perdido en el templo }\end{array}$ \\
\hline & Monja carmelita & Con rostro de cristal \\
\hline & Virgen María & $\begin{array}{l}\text { Resplandeciente como } \\
\text { sol }\end{array}$ \\
\hline & Virgen María & Luna resplandeciente \\
\hline & San Jerónimo & $\begin{array}{l}\text { Vestido, con barba entre- } \\
\text { cana y su león }\end{array}$ \\
\hline & San Juan Bautista & Corderito con diadema \\
\hline & San Antonio & Expresión unión mística \\
\hline \multirow[t]{4}{*}{$\begin{array}{l}\text { Jerónima de San } \\
\text { Bartolomé }\end{array}$} & San Juan Bautista & $\begin{array}{l}\text { Vestido como carmelita, } \\
\text { cordero }\end{array}$ \\
\hline & $\begin{array}{l}\text { Rostro de Cristo con } \\
\text { mano en la mejilla }\end{array}$ & Ojos graves, agonizante \\
\hline & Cristo de cuerpo entero & Ojos cerrados, muerto \\
\hline & Ecce Homo & $\begin{array}{l}\text { Sangre en el cuerpo } \\
\text { entero }\end{array}$ \\
\hline
\end{tabular}

Fuente: Elaboración propia a partir de la transcripción paleográfica de "Relación de lo que pasó en el convento de las Madres carmelitas descalzas de San José de la ciudad de los Ángeles" y "Primer Libro de profesiones del Convento de Carmelitas Descalzas de San José y Santa Teresa", 1604-1730. ACSTP. 
En las narraciones es factible entrever visos emocionales y afectivos. Gracias al uso de la iconografía y sus atributos se permiten asociaciones y la expresión de las diversas funciones emocionales que las escenas desempeñan. Los comportamientos individuales y colectivos, se vieron influenciados a manera de disposiciones conductuales, estas funcionaron como instrumentos de identidad social en el ámbito de una comunidad femenina recién formada. ${ }^{72}$ En este caso es factible reconocerlas como códigos que obedecen a regímenes culturales de clase. Los relatos aquí analizados, escritos por las monjas, permiten sugerir que el manejo de los afectos formó parte de un proceso de construcción de comunidades emocionales cohesionadas por sistemas de sentimientos. ${ }^{73}$ La gestualidad descrita en las pinturas representa un lenguaje virtual con funciones y significados sobredeterminados, aprobados canónicamente, compartidos y avalados socialmente. El siguiente párrafo expresa este tipo de codificaciones sociales.

más cosas de las dichas se han visto pero por ser tantas se dejan y porque cada día se ven otras y todo lo dicho hasta aquí [las monjas] están dispuestas a jurarlo ante cualquier persona para gloria y honra de Dios nuestro señor cuyas son estas obras y de nuestra gloriosa madre Santa Theresa de Jesús son las cosas dichas muy bien miradas con mucho acuerdo y muy de propósito de todas. ${ }^{74}$

Las descripciones muestran sistemas afectivos expresados verbalmente de diversas maneras, algunas veces aludieron a condiciones explícitas y reconocidas por todos, por ejemplo, cuando hablaban de la imagen de Cristo recargado sobe su mano, reflexionando en el

${ }^{72}$ La emoción es generada automáticamente cuando el sistema cognitivo tiende a evaluar un evento de forma consciente o inconsciente con el objeto de detectar las propiedades del mismo (facilitadoras, obstaculizadoras, modificadoras, positivas o negativas). Cada emoción se asocia con características fisiológicas diferenciables. Las funciones propias de estado mental son detonar una conducta, producir una respuesta y comunicarla hacia el exterior. Casacuberta, Qué es una emoción, 160.

${ }^{73}$ William M. Reddy, The Navigation of Feeling. A Framework for the History of Emotions (Cambridge: University Press, 2001). Para reforzar la idea de la existencia de que las monjas conforman una comunidad emocional puede verse a María Tausiet y James Amerlang, Accidentes del alma. Las emociones en la Edad Moderna (Madrid: Abada editores, 2009).

${ }^{74}$ ACSTP, "Relación de lo que pasó en el convento", f. 10v. 
momento posterior a la coronación "ensangrentado y afligido", para todas representó una imagen directa de dolor. Esta escena fue muy socorrida por las monjas debido al realismo que asociaba la carne sangrante y el rostro del Salvador. Una segunda lectura remitía a la muerte segura del hijo del Padre. ${ }^{75}$ Una posible razón de su repetición fue la existencia y circulación de una estampa que formó parte de la serie imaginada, inventada y grabada en el taller de Martín de Vos, de la cual se ha localizado su presencia en Puebla.

Si bien, las palabras expresaban estados de ánimo, también lo hicieron los silencios o las ausencias. Cuando Elvira de San José visualizó a una cruz sin cuerpo, pero escurriendo aún sangre, expresó una forma de miedo, Cristo ausente le remitió a la angustia que experimentaba en su papel como fundadora de la naciente comunidad, que se encontraba habitando a extramuros de la ciudad, teniendo como vecinos los tlaxilacales y barrios indígenas ubicados "del otro lado del río". Otra interpretación podía remitir a la ausencia del cuerpo en la cruz como un símbolo cristiano que ya no necesitaba corporeidad -como hoy en día la cruz no necesita un cuerpo para manifestar su significado-. Dios estaba presente entre ellas.

En las narraciones es factible localizar epítetos emocionales y codificaciones definidas a partir de fuentes canónicas y normativas que funcionaron como regímenes emocionales. ${ }^{76}$ Las palabras que definieron a las sensaciones estuvieron cargadas de sentido y su redacción expresaba la realidad subjetiva de la escribiente a partir de la utilización de adjetivos. Algunas veces éstos fueron utilizados para justificar giros corporales o alteraciones faciales que reflejaron "crestas emocionales" como cuando perdió la vista Francisca de la Natividad. También funcionaron para calificar la ambivalencia del signo, característica tan cara a la mística. A Melchora de la Asunción le pareció visualizar un rostro completo de Cristo "hermoso, risueño y alegre", pero en cuestión de segundos "la carne se abrió y cambio por un rostro ensangrentado, golpeado y afligido". ${ }^{77}$

${ }^{75}$ ACSTP, "Relación de lo que paso en el convento", f. 2.

${ }^{76}$ Se refiere a sistemas ideológicos y morales dominantes que prescriben la vida emocional de individuos y comunidades homogéneas.

${ }^{77}$ ACSTP, "Relación de lo que paso" Melchora de la Asunción, f. 7v y 8. 
Si se tuviera que caracterizar el régimen emocional del siglo XVII, seguramente la cultura del barroco hispanoamericano estaría definida por los principios de la teología mística. Ésta lo caracterizaría como un sistema de sufrimiento y ascesis como precondiciones de salvación eterna. No debemos entender que estas expresiones necesariamente se refieran al miedo o a la angustia, también podían referir a la solidaridad con el dolor del Cristo sufriente. Este esquema afectivo no siempre fue el mismo durante la época colonial, poco a poco y ya para el siglo XviII los textos femeninos privilegiarán a la melancolía como alternativa de expresión anímica. William Reddy habla de refugios emocionales como agentes de cambio, éstos reflejarían, para ese mismo siglo, las tensiones dentro del sistema emocional del cristianismo y las emociones cobrarían otro modelo de expresiones.

\section{A MODO DE CONCLUSIÓN}

Este documento puede considerarse un temprano ejemplo de un texto visual comunicativo. A través de las descripciones hechas por las religiosas es posible identificar sus diversas percepciones del mundo interior y espiritual. El orden de aparición y las religiosas involucradas, mediante los códigos y las unidades culturales trasmitieron ideas prefiguradas y mensajes religiosos. Todos estos estuvieron encaminados a reforzar las propuestas del cristocentrismo, la mariología y el santoral de la Orden. El estudio de estos grupos de imágenes permite evaluar su asociación con elementos ligados a la modernidad de los esquemas teológicos, ascéticos y emocionales del mundo barroco. El análisis de estos textos contribuye a definir el papel de las mujeres, en la temprana definición de la historia de las emociones, a la vez que sus expresiones formaron parte de regímenes emocionales que les permitieron expresar sus necesidades, sensibilidades y afectos de la modernidad femenina.

La relevancia de estas apariciones también puede verse en relación con la intención de promover y anclar el culto de santa Teresa en el virreinato y, por ende, en la América hispana. Estas tempranas visiones comenzaron a arraigarse en la religiosidad expresada por las maravillas y milagros que se suscitaron en los claustros novohis- 
panos y aun en el más amplio contexto del virreinato donde el culto popular de muchas imágenes estuvo basado en visiones personales de seculares y religiosos. Los panecitos de santa Teresa son un ejemplo claro de la posterior deformación del aparicionismo conventual. ${ }^{78}$

La instauración del primer Convento de Carmelitas Descalzas resultó de manera particular relevante. El monasterio cobró tal importancia que a lo largo de la primera mitad del siglo XVII el templo y el convento se terminaron, las profesiones fueron constantes y a principio del siglo XVIII la santa de Ávila fue proclamada patrona de la ciudad, con esto se mostraba la consolidación del carisma místico carmelitano en la ciudad de los Ángeles. ${ }^{79}$

\section{BiBLIOGRAFÍA}

Álvarez Santaló, León Carlos. Dechado barroco del imaginario moderno. Sevilla: Universidad de Sevilla, Secretariado de Publicaciones de la Universidad de Sevilla, 2010.

Amerlinck, María Concepción y Manuel Ramos. "Santa Teresa la Antigua”. En Conventos de monjas. Fundaciones en el México virreinal, 103-108. México: Condumex, 1995.

${ }^{78}$ Con la obra del cronista José Gómez de la Parra, Fundación y primer siglo. Crónica del primer convento de carmelitas descalzas en Puebla 1604-1704 (México: Universidad Iberoamericana, Comisión Puebla v Centenario, 1992) se llega a la hipérbole del aparicionismo femenino carmelitano. Como un caso específico de un estudio de caso asociado véase Martha Lilia Tenorio, De panes y sermones: el milagro de las "panecitos" de Santa Teresa (México: El Colegio de México, 2001). Ésta es la relación más completa del proceso de ratificación del "milagro" y el subsecuente cuestionamiento y proceso inquisitorial a que fue sometido. Véase también Antonio Rubial García y María de Jesús Díaz Nava, "La santa es una bellaca y nos hace muchas burlas". El caso de los panecitos de Santa Teresa en la sociedad novohispana del siglo Xvı", Estudios de Historia Novohispana (24) (2001): 53-75.

${ }^{79}$ AAP, Libro de Patronatos de La Muy Noble y muy Leal Ciudad de los Ángeles. A principios del siglo xviII se instaló un alto relieve en piedra de Villerías en el lado derecho de la puerta principal de la basílica catedral de Puebla y representa a Santa Teresa en el momento en que un ángel la hiere con una flecha en el corazón, se trata de la escena de la Transverberación, el escudo de la izquierda reza Vulnerasti cor meum (heriste mi corazón) y el de la derecha Amore Langueo (me consumo de amor). Hugo Leicht, Las calles de Puebla (Puebla y México: Junta de Mejoramiento Moral, Cívico y Material del Municipio de Puebla, 1986), 150. 
ArrivÉ, Michel e Izabel VILELA. "Lenguaje e inconsciente en Freud: representaciones de las palabras y representaciones de las cosas". En "Semiótica y psicoanálisis". Tópicos del Seminario (44) (2004): 51-76.

Atienza, Ángela. "Santa Teresa en los conventos de monjas de Nueva Espańa”, Hispania Sacra LXviI(136) (2015): 391-399.

. "En permanente construcción. La recreación de la figura de santa Teresa en las semblanzas biográficas de sus hijas", Hispania Sacra LXVII (136) (2015): 575-612.

BÁEz, Linda. Mnemosine novohispánica. Retórica e imágenes en el siglo XVI. México: UnAM, IIE, 2005.

Báez Macías, Eduardo. Fray Agustín de la Madre de Dios, Tesoro escondido del Monte Carmelo Mexicano. México: unAM, 1986.

Baranda L. Nieves y María del Carmen Marín PiÑa. Letras en la celda. Cultura escrita de los conventos femeninos en la España moderna. Madrid y Frankfurt: Iberoamericana-Vervuert, 2014.

Beardsley, Curtis y John Hospers. Estética. Historia y fundamentos. Madrid: Cátedra, 1990, 39-40.

Bellinger, Gerhard et al., Diccionario ilustrado de la Biblia. León: Editorial Everest, 1985, 482.

Carducho, Vicente. Diálogos de la pintura. Su defensa, origen esencia, definición, modos y diferencias [Madrid: 1633]. Traducción y edición. Francisco Calvo Serraller (Madrid: 1979).

Casacuberta, David. Qué es una emoción. Barcelona: Crítica, 2000.

De Stefano, Michael. "Miracles and Monasticism in Mind-Colonial Puebla, 1600-1750: Charismatic Religion in a Conservative Society". Tesis de Doctorado, University of Florida, 1977.

Eco, Umberto. Historia de la belleza. Barcelona: Lumen, 2004, 176-178.

. Tratado de semiótica general. Barcelona: Lumen, 2000, 81-156.

Estampa europea de los siglos XV y XVI, Colección Manuel Álvarez Bravo. México: Museo Sumaya, 1998.

Étienne, Souriau. Diccionario Akal de Estética. Madrid: Akal, 1998.

Foucault, Michel. Las palabras y las cosas, México: Siglo XXI, 1988, 53-83. 
Freedberg, David. El poder de las imágenes, estudios sobre la historiay la teoria la respuesta. España: Catedra, Arte, Grandes temas, 1992. Furió, Vicenc. El arte del granado antiguo. Obras de la colección Furió, Barcelona: Universidad de Barcelona, 2000.

GÉLIs, Jacques. “El cuerpo, la Iglesia y lo sagrado”. En Historia del cuerpo, Renacimiento a la Ilustración. Vol. 1, dir. Georges Vigarello, 27-112. Espańa: Taurus, 2005.

Gombrich, Ernst. Los usos de las imágenes, Estudio sobre la función social del arte y la comunicación visual. México: Fondo de Cultura Económica, 2003.

. Norma y forma. Madrid: Alianza Forma, 1984.

Gómez de la PARra, José. Fundación y primer siglo. Crónica del primer convento de carmelitas descalzas en Puebla 1604-1704. México: Universidad Iberoamericana, Comisión Puebla v Centenario, 1992.

Holanda, Francisco de. De la pintura antigua (1548), trad. Manuel Denis. Madrid: 1921.

LAVrin, Asunción. "Espiritualidad en el claustro novohispano del siglo xviı". Colonial Latin American Review 4(2) (1995): 155-180.

. "De su puño y letra. Epístolas conventuales". En Elmonacato femenino en el imperio español. Manuel Ramos Medina, 43-59. México: Condumex, 1995.

. "La celda y el siglo. Epístolas conventuales". En Mujer y cultura en la Colonia hispanoamericana, ed. Mabel Moraña, 139159. Pittsburg: Instituto Internacional de Literatura Iberoamericana, University of Pittsburg, 1996.

Lavrin, Asunción y Rosalva Loreto. Monjas y beatas. La escritura femenina en la espiritualidad barroca novohispana. Siglos XVII y XVIII. México: Universidad de las Américas, Archivo General de la Nación, 2002.

Lavrin, Asunción y Rosalva Loreto. Diálogos espirituales. Manuscritos femeninos hispanoamericanos. Siglos XVI-XIX. Puebla: Universidad de las Américas, Instituto de Ciencias Sociales y Humanidades de la Universidad Autónoma de Puebla, 2006.

Le Goff, Jacques. “¿La cabeza o el corazón?” El uso político de la metáforas corporales durante la Edad Media”. En Fragmentos 
para una historia del cuerpo humano. Parte Tercera. Michel Feher et al., 12-26. Madrid: Taurus, 1990.

Leicht, Hugo. Las calles de Puebla. Puebla y México: Junta de Mejoramiento Moral, Cívico y Material del Municipio de Puebla, 1986.

LORETo, Rosalva. "Las pruebas del milagro en el proceso de beatificación de la Madre María de Jesús”. En Historia de la Iglesia en el siglo XIX. México: El Colegio de México, El Colegio de Michoacán, Instituto Mora, UAM-Iztapalapa, Condumex, 1998, 351-369.

- Los conventos de mujeres en el mundo urbano de la Puebla de los Ángeles del siglo XVIII. México: El Colegio de México, 2000.

. "La función social y urbana del monacato femenino novohispano". En La iglesia en Nueva España. Problemas y perspectivas de Investigación, coord. María del Pilar Martínez López Cano. México: unAM, 2010, 12-26.

Martínez Ripoll, Antonio. El barroco en Europa. Historia 16. Madrid: Historia Viva, 1999.

PACHeco, Francisco. Arte de la pintura, su antigüedad y grandezas (1641). Madrid: Librería de D. León Pablo Villaverde, 1871.

PANOFSKy, Erwin. Estudios sobre iconología [1939]. Madrid: Alianza, 2008.

Picinelli, Filippo. Los cuerpos celestes, libro I (El mundo simbólico), índices y edición de textos latinos e italianos de Bárbara Skinfill Nogal. Zamora: El Colegio de Michoacán, 1997.

Praz, Mario. Mnemosyne. El paralelismo entre la literatura y las artes visuales. Madrid: Taurus, 1979.

Ragon, Pierre. "Sebastián de Aparicio. Un santo mediterráneo en el altiplano mexicano". Estudios de Historia Novohispana (23) (2000): 17-46.

Ramos, Manuel. Misticas y descalzas. México: Universidad Iberoamericana, 1990.

RedDy, William M. The Navigation of Feeling. A Framework for the History of Emotions. Cambridge: Cambridge University Press, 2001.

Ronsenwein, Barbara H. "Problems and Methods in the History of Emotions". Journal of the History and Philosophy of the Emotions 1(1) (2010): 2-32. 
. "Worrying about Emotions in History". American Historical Review 107(3) (2002): 821-845.

Rubial, Antonio. "Los santos milagreros y malogrados de la Nueva España”. En Manifestaciones religiosas en el mundo colonial americano. Vol. I, coord. Clara García Ayluardo y Manuel Ramos Medina, 71-105. México: Condumex, INAH, Universidad Iberoamericana, 1993.

. "Cuerpos milagrosos. Creación y culto de las reliquias novohispanas". Estudios de Historia Novohispana (18) (1998): 3-30.

Rubial Antonio y María de Jesús Díaz Nava, “'La santa es una bellaca y nos hace muchas burlas'. El caso de los panecitos de santa Teresa en la sociedad novohispana del siglo Xviı". Estudios de Historia Novohispana (24) (2001): 53-75.

Salmeron, Pedro. Vida de la venerable madre Isabel de la Encarnación, ed. Rice Ann Robin. Pamplona: Universidad de Navarra, Iberoamericana-Vervuert, Bonilla Artigas Editores, 2013.

SÁnchez, Gabriela. "Relicarios novohispanos a través de una muestra de los siglos Xvi al Xviı". Tesis de Maestría en Historia del Arte Colonial, FFyL-unam, 2004.

Stoichita, Víctor I. El ojo mistico. Pintura y visión religiosa en el Siglo de Oro español. Madrid: Alianza Forma, 1996.

TANQuerey, Ad. Compendio de teología ascética y mistica. Roma: Sociedad de San Juan Evangelista, 1930.

TATARKIEWICZ, Władysław. Historia de la estética III. La estética moderna 1400-1700, Madrid: Akal, 1991, 53-75.

TAusiet María y James Amerlang. Accidentes del alma. Las emociones en la Edad Moderna. Madrid: Abada editores, 2009.

TAYLOR, William B. Marvels and Miracles in Late Colonial Mexico. Three Texts in Context. Albuquerque: University of New Mexico Press, 2011.

Tenorio, Martha Lilia. De panes y sermones: el milagro de las "panecitos" de santa Teresa. México: El Colegio de México, 2001, 50.

VELDMAN, Ilja M. Images for the Eye and Soul: Function and Meaning in Netherlandish Prints (1450-1650). Leiden: Primavera Pers, 2006.

William Christian. Apariciones en Castilla y Cataluña (siglos XIVXVI). Madrid: Nerea, 1990. 